\title{
The Role of Nature-Based Solutions for Improving Environmental Quality, Health and Well-Being
}

\author{
Hai-Ying Liu ${ }^{1, *}$, Marion Jay ${ }^{2}$ and Xianwen Chen ${ }^{3,4}$ (D) \\ 1 Department of Environmental Impacts and Sustainability, NILU-Norwegian Institute for Air Research, \\ P.O. Box 100, 2027 Kjeller, Norway \\ 2 Adelphi Research gGmbH, Alt-Moabit 91, 10559 Berlin, Germany; jay@adelphi.de \\ 3 Oslo Department, NINA-Norwegian Institute for Nature Research, Sognsveien 68, 0855 Oslo, Norway; \\ xianwen.chen@gmail.com \\ 4 Department of Business Administration, Inland School of Business and Social Sciences, Inland Norway \\ University of Applied Sciences, P.O. Box 400, 2418 Elverum, Norway \\ * Correspondence: hyl@nilu.no; Tel.: +47-6389-8048
}

Citation: Liu, H.-Y.; Jay, M.; Chen, X. The Role of Nature-Based Solutions for Improving Environmental Quality, Health and Well-Being. Sustainability 2021, 13, 10950. https://doi.org/ $10.3390 /$ su131910950

Academic Editor:

Samuel Asumadu-Sarkodie

Received: 20 July 2021

Accepted: 25 September 2021

Published: 1 October 2021

Publisher's Note: MDPI stays neutral with regard to jurisdictional claims in published maps and institutional affiliations.

Copyright: () 2021 by the authors. Licensee MDPI, Basel, Switzerland. This article is an open access article distributed under the terms and conditions of the Creative Commons Attribution (CC BY) license (https:// creativecommons.org/licenses/by/ $4.0 /)$.

\begin{abstract}
Nature-based solutions ( $\mathrm{NbS}$ ) have been positioned and implemented in urban areas as solutions for enhancing urban resilience in the face of a wide range of urban challenges. However, there is a lack of recommendations of optimal $\mathrm{NbS}$ and appropriate typologies fitting to different contexts and urban design. The analytical frameworks for NbS implementation and impact evaluation, that integrate $\mathrm{NbS}$ into local policy frameworks, socio-economic transition pathways, and spatial planning, remain fragmented. In this article, the $\mathrm{NbS}$ concept and its related terminologies are first discussed. Second, the types of $\mathrm{NbS}$ implemented in Europe are reviewed and their benefits over time are explored, prior to categorizing them and highlighting the key methods, criteria, and indicators to identify and assess the NbS's impacts, co-benefits, and trade-offs. The latter involved a review of the websites of 52 projects and some relevant publications funded by EU Research and Innovation programs and other relevant publications. The results show that there is a shared understanding that the $\mathrm{NbS}$ concept encompasses benefits of restoration and rehabilitation of ecosystems, carbon neutrality, improved environmental quality, health and well-being, and evidence for such benefits. This study also shows that most NbS-related projects and activities in Europe use hybrid approaches, with $\mathrm{NbS}$ typically developed, tested, or implemented to target specific types of environmental-social-economic challenges. The results of this study indicate that $\mathrm{NbS}$ as a holistic concept would be beneficial in the context of climate action and sustainable solutions to enhance ecosystem resilience and adaptive capacity within cities. As such, this article provides a snapshot of the role of $\mathrm{NbS}$ in urban sustainability development, a guide to the state-of-the-art, and key messages and recommendations of this rapidly emerging and evolving field.
\end{abstract}

Keywords: biodiversity; blue infrastructure; climate adaptation and mitigation; ecosystem services; green infrastructure; sustainable development goals; urban sustainability

\section{Introduction}

Climate change and urbanization have resulted in a broad range of societal challenges for urban areas [1], such as the loss or degradation of natural areas, soil sealing, drought, and flooding, which pose further challenges to biodiversity, ecosystem functioning, delivery of the ecosystem services (ES) (e.g., clean air, water, and soil), and consequently human health and well-being [2]. Almost 55\% of the world's population lives in urban areas today, which will increase to over $68 \%$ by 2050 [3,4]. Thus, two of the main future challenges are to design sustainable cities that can adapt to the changing needs of their inhabitants and to the evolution of environmental conditions. Both the United Nations Habitat III "New Urban Agenda" [5] and the Sustainable Development Goal (SDG) 11 "Make cities and human settlements inclusive, safe, resilient, and sustainable" address the needs for 
innovative approaches and solutions in urban management to strengthen urban resilience and sustainably neutralize the negative effects of urbanization and climate change on humans and nature [6]. One promising way to achieve these challenges is to adopt naturebased solutions $(\mathrm{NbS})$ in the management and design of urban areas [7].

The term $\mathrm{NbS}$ has been advocated by policymakers, governance bodies, scientists, and non-governmental organizations (NGOs). Different definitions of NbS emerged throughout time, including two of international governmental and non-governmental bodies, which greatly shaped the $\mathrm{NbS}$ discourse in recent years, i.e., the International Union for Conservation of Nature's (IUCN) and the European Commission's (EC) definitions [8,9]. However, there is no agreed clarification about the differences and commonalities of these two $\mathrm{NbS}$ definitions. In addition, the $\mathrm{NbS}$ concept is clearly connected to other concepts, such as ecosystem-based adaptation/mitigation (EbA/EbM), green infrastructure (GI), blue infrastructure (BI), blue/green infrastructure/green/blue infrastructure (BGI/GBI), and ecological engineering (EE). Although the extent of similarities and distinctions of these concepts are being discussed in scientific literature, it is not clear whether $\mathrm{NbS}$ is distinctly different from these other concepts either [10].

Regardless of this heterogeneity of definitions, $\mathrm{NbS}$ are tested through experimentation, designed, and implemented all around the globe, and as such they have been scientifically assessed. Many studies found that NbS support biodiversity conservation [11-13], generate additional environmental-economic-societal benefits [14], and provide a basis for climate change mitigation and adaptation [15]. Several $\mathrm{NbS}$ approaches already exist, such as the $\mathrm{NbS}$ impact evaluation framework [16], the NbS handbook [17], the NbS core principles [10], and the NbS global standard [18]. Furthermore, information marketing and collaboration are promoted on the $\mathrm{NbS}$ repository, see for example the EU repository of NbS-Oppla [19]. However, the existing conceptual and practical knowledge of $\mathrm{NbS}$ still remain fragmented and there is a need to develop a unified framework including its methods, criteria, and indicators to measure NbS implementation in different climaticenvironmental-socio-economic conditions, to assess its benefits and trade-offs in diverse structures and configurations (e.g., mix of vegetation and trees, species, shape, spatial distribution of public green space, and vegetation coverage), and to exchange experiences, solutions, and good practices, while at the same time enhancing and fostering market opportunities for innovative companies.

As such, the first part of this paper focuses on the concept of NbS (Section 2). The first objective is thus to review the concept of $\mathrm{NbS}$, including a comparison with other related concepts. We proceed with this objective in four steps: (i) describing and analyzing $\mathrm{NbS}$ definitions and primary attributes as proposed by the EC and the IUCN (Section 2.1), (ii) describing and categorizing NbS-related concepts (Section 2.2), (iii) analyzing the frequency of the various NbS-related concepts in scientific literature over time (Section 2.3), and (iv) examining the emergence over time in broader discourses and the geographical coverage for the different NbS-related concepts (Section 2.4) (Figure 1).

The second part of this paper focuses on the implementation and assessment of $\mathrm{NbS}$ (Section 3). The second objective is thus to investigate the state-of-the-art of the $\mathrm{NbS}$, involving two dimensions: global frameworks of $\mathrm{NbS}$ governance (Section 3.1), and implementation and assessment of $\mathrm{NbS}$ (Section 3.2). For the governance dimension, we focus on three aspects: description of international intra-governmental and non-governmental frameworks (Section 3.1.1), EU governmental framework (Section 3.1.2), and Chinese governmental framework (Section 3.1.3). For the implementation and assessment dimension, we address four aspects, including (i) a set of criteria used to characterize $\mathrm{NbS}$ and the type of NbS implemented (Section 3.2.1), (ii) challenges addressed by the NbS and the key performance indicators (KPIs) to assess NbS impact (Section 3.2.2), (iii) NbS data and metadata platforms (Section 3.2.3), and (iv) NbS stakeholders and their priorities for $\mathrm{NbS}$ implementation (Section 3.2.4) (Figure 1).

Section 4 discusses the main issues raised in Sections 2 and 3 and suggests areas where further development is needed. Section 5 offers conclusions. 


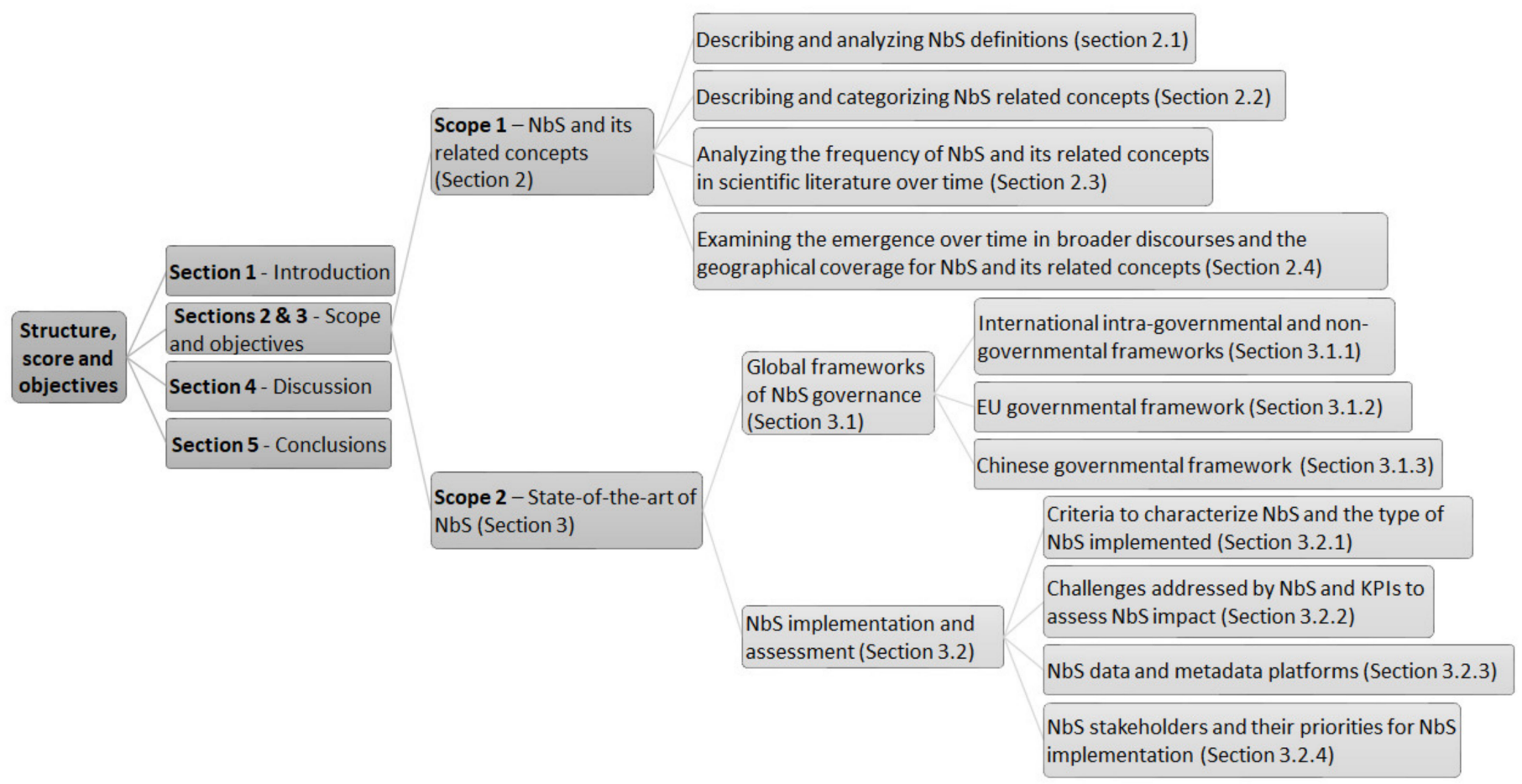

Figure 1. Structure, scope, and objectives of the paper.

\section{An Analysis of NbS Terminologies}

\subsection{Nature-Based Solutions Timeline and Definitions}

The term NbS first emerged in the early 2000s, in the discussions on land-use management and planning and water resource management, including the use of wetlands for wastewater treatment [20]. From the mid-2000s, the NbS also began to appear in literature on industrial design [21]. In the year 2008, the NbS were first used by the World Bank to promote nature as a source of solutions to challenges associated with climate change [22,23]. In the year 2009, the IUCN referred to NbS in a position paper for the United Nations (UN) Framework Convention on Climate Change. Afterwards, the term $\mathrm{NbS}$ was quickly taken up, supported, and broadened by the IUCN and by the EC [8,10,18,24-28], and became more widely used in literature relating to methods for increasing resilience to the impacts of climate change. The EC has developed an EU Research and Innovation (R\&I) agenda on NbS in its Seventh Framework Program (FP7) and H2020 Framework Program [9,29], and is continually addressing NbS in its Green Deal Calls [30] and Horizon Europe Calls [31]. The timeline shown in Figure 2 highlights the major milestones in the evolution of the $\mathrm{NbS}$ concept, starting from the first use of the term $\mathrm{NbS}$, to the $\mathrm{NbS}$ at the core of the $\mathrm{EU}$ R\&I agenda.

So far, research on the $\mathrm{NbS}$ and its related concept is still very limited, but it has been diversified. In the USA, for example, nature-based infrastructure [32] and engineering with nature [33] are the two common concepts, which overlap with the concept of $\mathrm{NbS}$ in several aspects. There are also some differences in the definition of $\mathrm{NbS}$ between the EC and the IUCN. The IUCN in the year 2016 [8] (p. 166) defined NbS as "actions to protect, sustainably manage, and restore natural or modified ecosystems, that address societal challenges effectively and adaptively, simultaneously providing human well-being and biodiversity benefits". The EC first defined NbS in the year 2015 [9] (p. 24) as "NbS are inspired and supported by nature and simultaneously provide environmental, social, cultural and economic benefits", and then revised its definition in the year 2019 [34] as "NbS are inspired and supported by nature, which are cost-effective, simultaneously provide environmental, social and economic benefits and help build resilience. Such solutions bring more, and more diverse, nature and natural features and processes into cities, landscapes 
and seascapes, through locally adapted, resource-efficient and systemic interventions". For the EC, NbS are understood as "living solutions" aimed at helping society to cope with various environmental, social, and economic challenges in a sustainable manner. They are inspired by nature, supported by nature, or copies from nature [35]. The IUCN defined $\mathrm{NbS}$ as "actions" and believes that the basic approach to NbS is to actively apply sustainable management and conservation of natural resources to meet major societal challenges, such as climate change, food security, water security, and natural disasters $[7,8]$.

\begin{tabular}{|c|c|}
\hline 8 & $\begin{array}{l}\text {-First use of the term NbS by the World Bank to highlight the importance of biodiversity conservation for climate change mitigation } \\
\text { and adaptation [23] } \\
\text { •The World Bank Report on 'Biodiversity, Climate Change and Adaptation: NbS from the World Bank Portfolio' [22] }\end{array}$ \\
\hline & -IUCN's position paper on 'No time to lose - make full use of NbS in the post-2012 climate change regime' [28] \\
\hline & $\begin{array}{l}\text { - IUCN-WCPA, TNC, UNDP, WCS, The World Bank and WWF's report on 'Natural Solutions: Protected areas helping people cope with } \\
\text { climate change' [24] }\end{array}$ \\
\hline & •The IUCN's 'Programme 2013-2016 NbS-1/3 of IUCN's Global Programme’ [25] \\
\hline & $\begin{array}{l}\text {-IUCN put forward NbS in the context of the climate change negotiation in Paris [26] } \\
\text {-IUCN suggested seven principles as comprising the core of NbS concept [17] } \\
\text {-IUCN's resolution on defining NbS [27] } \\
\text {-IUCN's report on NbS to address global societal challenges [8] } \\
\text {-IUCN's core principles for successfully implementing and upscaling NbS [17] } \\
\text {-IUCN's global standard for NbS: first edition [18] }\end{array}$ \\
\hline & $\begin{array}{l}\text {-BiodivERsA workshop on 'NbS in a BiodivERsA context' [107] } \\
\text {-EC adopted the concept of NbS for its R\&I programme Horizon } 2020 \text { [9] } \\
\text {-EC defined NbS as “actions which are inspired by, supported by or copied from nature" [9, 34]. } \\
\text {-NbS at core of EU R\&I agenda [9, 29] } \\
\text {-NbS addressed in EU Green Deal Calls [30] } \\
\text {-NbS addressed in EU Horizon Europe Calls [31] }\end{array}$ \\
\hline
\end{tabular}

Figure 2. Timeline of the development of the nature-based solutions (NbS) concept.

To compare, the IUCN's definition is concerned with human well-being and biodiversity, while the EC's definition explicitly considers cost-effectiveness, resource-use efficiency, and economic benefits, which were not mentioned in the IUCN definition. Although the IUCN's definition does not explicitly state cost-effectiveness, resource-use efficiency, or economic benefits $[8,18,36]$, the goals of "sustainably manage" and "effectively and adaptively" may suggest that the IUCN's definition is concerned with cost-effectiveness, efficiency, and economics, depending on one's definition and interpretation of "sustainably" and "effectively". Considering the following, if an NbS is not cost-effective, efficient, or beneficial, the NbS is likely not going to be implemented and sustainably managed.

In addition, biodiversity and its benefits are not only important for humans, but also for other species such as plants, insects, animals, and microbiota. Biodiversity and its benefits, which is an important goal of utilizing NbS according to the IUCN's definition, is not explicitly included in the EC's definition. Instead, the EC definition includes an explanation of biodiversity as "more, and more diverse, nature, and natural features and processes" which indicates that NbS must therefore benefit biodiversity and support the delivery of a range of ES as well [34,37].

Furthermore, geographically and demographically, the EC's definition for NbS emphasizes on more sustainable and resilient societies through growth and job creation, mostly in urban contexts. It is unclear whether the $\mathrm{EC}^{\prime} \mathrm{s} \mathrm{NbS}$ definition considers rural areas, although rural areas may be included in the broad interpretation of "landscapes and 
seascapes". The IUCN's definition was developed from a global perspective, which does not have a specific geographical or demographic focus.

To summarize, we find that the IUCN's NbS definition and the EC's NbS definition are worded differently, but cover similar aspects, both defining $\mathrm{NbS}$ as living solutions or actions that utilize nature to deliver multiple benefits and address multiple challenges in a broad way.

\subsection{Nature-Based Solutions-Related Concepts}

The concept of $\mathrm{NbS}$ is very closely related to the concepts of EE, GI, BI, BGI/GBI, and $\mathrm{EbA} / \mathrm{EbM}$. Table 1 shows the definition and key references of these concepts. We can see that it is not quite clear whether NbS is distinctly different from these other concepts, and a range of crossovers appears throughout the concepts.

The concepts related to the GI, BI, and BGI/GBI are the targeted approaches to specific activities or land use problems. The GI mainly refers to the land, including land reserves, farmland for intensive agriculture land, ecological corridors and underground tunnels built for animals, as well as urban parks and green roofs. The BI is mainly related to water, including coastal areas, rivers, lakes, waterway channels, wetlands, floodplains, and some human design elements (e.g., artificial channels, ponds, reservoirs, and urban sewage). Generally, BI always appears with GI, so it is commonly considered jointly under the headings of BGI or GBI. The green and blue elements of this infrastructure are considered as natural elements that can bring ecological, economic, and social benefits. These concepts also help to understand the benefits that nature brings to human society.

The ecosystem-based concepts $\mathrm{EbA}$ and $\mathrm{EbM}$ recognize that human and cultural diversity are integral parts of the ecosystem and that conservation and utilization need to be balanced. The EbA and EbM are about ecosystem-based strategies for adapting and mitigating to climate change, respectively. Generally, EbA and EbM appear as one term as $\mathrm{EbA} / \mathrm{EbM}$ [38]. The protection of ecosystem structure and function and the maintenance of ES should be the priority objectives of the ecosystem approach, and the ecosystem must be managed within its functional scope [39]. The ecosystem-based concepts can guide and realize the fair management of natural resources, to reflect and maintain different needs and values. The EbA/EbM concept also more explicitly involves the objective of addressing climate changes and supporting adaptation and mitigation through natural solutions. In a broader context, the concept and practice of ecological restoration can be linked here as EE. The EE approach, which covers a wide range of activities and interventions, obviously seeks to supplement technology-based infrastructure with natural alternatives and can therefore be considered as an application of $\mathrm{NbS}$.

Table 1. Selected terminologies and their definitions found in the literature related to naturebased solutions.

\begin{tabular}{lll}
\hline Terminology & Definition & Key References \\
\hline & Refers to the sustainable & \\
& management and use of & \\
& nature for tackling & \\
& socio-environmental \\
& challenges, including issues & \\
Nature-based Solutions (NbS) & such as climate change, \\
biodiversity degradation, & water security, water \\
& pollution, food security, \\
& human health, and disaster \\
& risk management. \\
\hline
\end{tabular}


Table 1. Cont.

\begin{tabular}{|c|c|c|}
\hline Terminology & Definition & Key References \\
\hline Ecological Engineering (EE) & $\begin{array}{l}\text { Sustainable ecosystem } \\
\text { designed for the common } \\
\text { interests of human society and } \\
\text { natural environment is to } \\
\text { integrate society with its } \\
\text { natural environment. } \\
\text { A strategically planned }\end{array}$ & {$[40,41]$} \\
\hline Green Infrastructure (GI) & $\begin{array}{l}\text { network of natural and } \\
\text { semi-natural areas with other } \\
\text { environmental features } \\
\text { designed and managed to } \\
\text { deliver a wide range of ES. }\end{array}$ & {$[42,43]$} \\
\hline Blue Infrastructure (BI) & $\begin{array}{l}\text { Refers to urban infrastructure } \\
\text { relating to water bodies, } \\
\text { defined as a network } \\
\text { providing the "ingredients" } \\
\text { for solving urban and climatic } \\
\text { challenges by building with } \\
\text { nature. }\end{array}$ & [44] \\
\hline $\begin{array}{l}\text { Blue/Green } \\
\text { infrastructure/Green/Blue } \\
\text { Infrastructure (BGI/GBI) }\end{array}$ & $\begin{array}{l}\text { An interconnected network of } \\
\text { natural and designed } \\
\text { landscape components, } \\
\text { including water bodies and } \\
\text { green and open spaces, which } \\
\text { provide multiple functions. }\end{array}$ & {$[45,46]$} \\
\hline $\begin{array}{l}\text { Ecosystem-based } \\
\text { Adaptation/Mitigation } \\
(\mathrm{EbA} / \mathrm{EbM})\end{array}$ & $\begin{array}{l}\text { The use of biodiversity and } \\
\text { ecosystem services as part of } \\
\text { an overall } \\
\text { adaptation/mitigation } \\
\text { strategy to help people to } \\
\text { adapt/mitigate the adverse } \\
\text { effects of climate change. } \\
\text { Policies and measures that } \\
\text { consider the role of ES in } \\
\text { reducing the vulnerability of } \\
\text { society to climate change, in a } \\
\text { multi-sectoral and multi-scale } \\
\text { approach. }\end{array}$ & {$[47-50]$} \\
\hline
\end{tabular}

\subsection{Temporal Analysis of the Literature for Nature-Based Solutions and Their Related Concepts}

The temporal analysis aimed to analyze the frequency of the $\mathrm{NbS}$ and their related concepts in scientific literature over time. It was obtained by using search string in Google Scholar between 2008 and 2020, using the following key words in title-abstractkeywords respectively, i.e., 'nature-based solutions', 'ecological engineering', 'green infrastructure', 'blue infrastructure', 'blue/green infrastructure' or 'green/blue infrastructure', 'ecosystem-based adaptation' or 'ecosystem-based mitigation'. Each provided 10,860, $130,560,58,730,2999,2004$, and 5676 hits, respectively. At the end, a total of 210,829 scientific papers, published between 2008 and 2020, which contained any of the concepts listed in Table 1 in their title, keywords, or abstract were obtained from Google Scholar on 18 May 2021 (the day we implemented the temporal analysis). The objective of this temporal analysis is to analyze the frequency of occurrence for $\mathrm{NbS}$ and their related concepts found in the literature, and therefore it was not necessary to review the papers in detail. Figure 3 summarizes the frequency of their use, which illustrates time-series trends as well. As expected, as a relatively new ecological term, $\mathrm{NbS}$ is steadily rising, with a recent and intense rise since 2016. NbS has been more frequently used in contrast to $\mathrm{EbA} / \mathrm{EbM}$, 
BI, and BGI/GBI since 2016. GI and EE are much more frequently used in contrast to other terms.

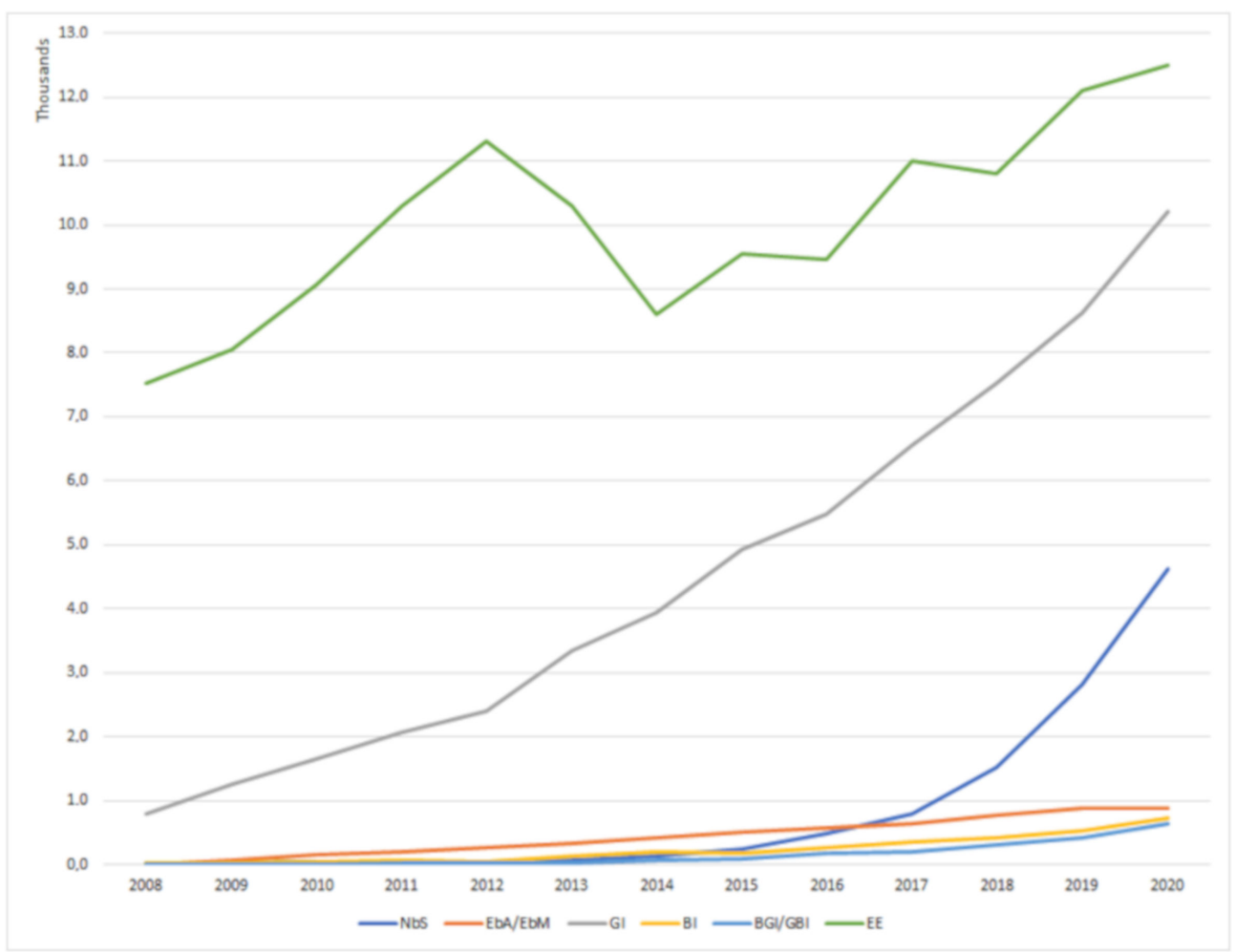

Figure 3. The frequency of occurrence of different terms found in the literature relating to naturebased solutions.

\subsection{Google Trends Analysis for Nature-Based Solutions and Their Related Concepts}

Google trends analysis was carried out to examine the emergence of $\mathrm{NbS}$ and their related concepts over time in broader discourses and their geographical coverage. Google Trends [51] allows for the examination of relative search volumes of terms over time to illustrate trends in popularity of terms that are more mainstream than academic and is an indicator of movements from the academic literature to more layman outlets, e.g., through media and into popular science.

Google trends analysis was performed by using search strings in Google Trends between 2004 (which is around the time when Google Trends started) and 18 May 2021 (the day we implemented the Google Trends analysis), using the following keywords (listed in Table 1) respectively, i.e., 'nature-based solutions', 'ecological engineering', 'green infrastructure', 'blue infrastructure', 'blue/green infrastructure' or 'green/blue infrastructure', 'ecosystem-based adaptation' or 'ecosystem-based mitigation'. Figure 4 shows the trend for the terms ' $\mathrm{GI}^{\prime}, \mathrm{BI}^{\prime},{ }^{\prime} \mathrm{NbS}$ ', and 'EE' together from 2004 to 18 May 2021. The terms which are used in the academic literature but not widely used by the public, such as $\mathrm{EbA} / \mathrm{EbM}$ and BGI/GBI, do not register a trend due to insufficient search volume. The term NbS shows an increase in search volume since around 2014, reflecting an increasing public interest in the subject. The search volumes of GI, BI, and EE stopped growing since about ten years ago. GI has much larger search volumes than $\mathrm{BI}, \mathrm{EE}$, and $\mathrm{NbS}$. The web volume for the term BI was much higher than NbS. 


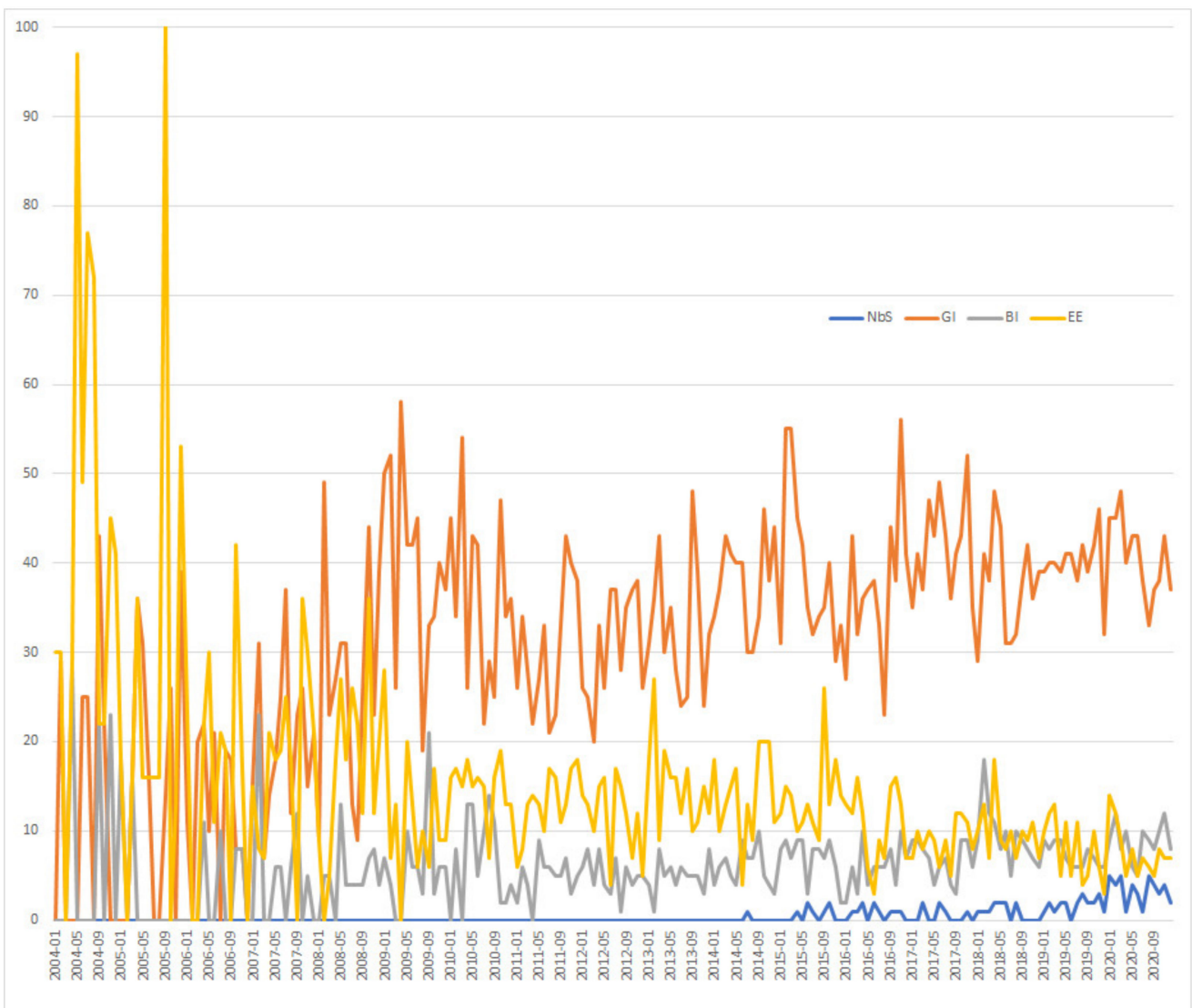

Figure 4. Trend in the terms ' $\mathrm{NbS}^{\prime}$, ' $\mathrm{GI}^{\prime}$, ' $\mathrm{BI}^{\prime}$, and ' $\mathrm{EE}^{\prime}$ over time. The $y$-axis is a relative volume expressed between 0 and 100, where the maximum search volume is set to 100 .

In terms of geographical coverage, the interest levels of using these terms are different in different regions of the world within different contexts, partly due to the uptake in policy documents and social media. For instance, even though the concept of $\mathrm{NbS}$ has gained momentum and recognition in several international fora, including the UN Framework Convention on Climate Change (UNFCCC) [52], the Convention on Biological Diversity (CBD) [53], the Sendai Framework for Disaster Risk Reduction (DRR) [54], the World Economic Forum [55], and the UN Environment Assembly [56], among others, the concept of $\mathrm{EbA} / \mathrm{EbM}$ is much more present there than $\mathrm{NbS}$ and some parties are still reluctant to introduce a new concept of $\mathrm{NbS}$.

Figure 5 shows the interest by regions for these terms since 2004. Values are calculated as a value from $0 \%$ to $100 \%$. Almost $100 \%$ of the searches in China were on EE. However, because Google has been banned by the Chinese government since 2010, this result largely reflected the searches in China between 2004 and 2010. In contrast, in France, searches on GI accounted for around $80 \%$ of all searches. Overall, we can see that the term $\mathrm{NbS}$ is most popular in European countries, such as the Netherlands, the UK, and Switzerland. The usage of the term NbS is also widespread in Singapore and Canada. The GI term is most used in France, the UK, and Ireland. The BI term is widespread in India, Australia, and Canada, followed by the UK and the USA. There is not enough data to show in which location the terms ' $\mathrm{EbA} / \mathrm{EbM}^{\prime}$ and 'BGI/GBI' were most popular during the timeframe of 2004-18 May 2021. 


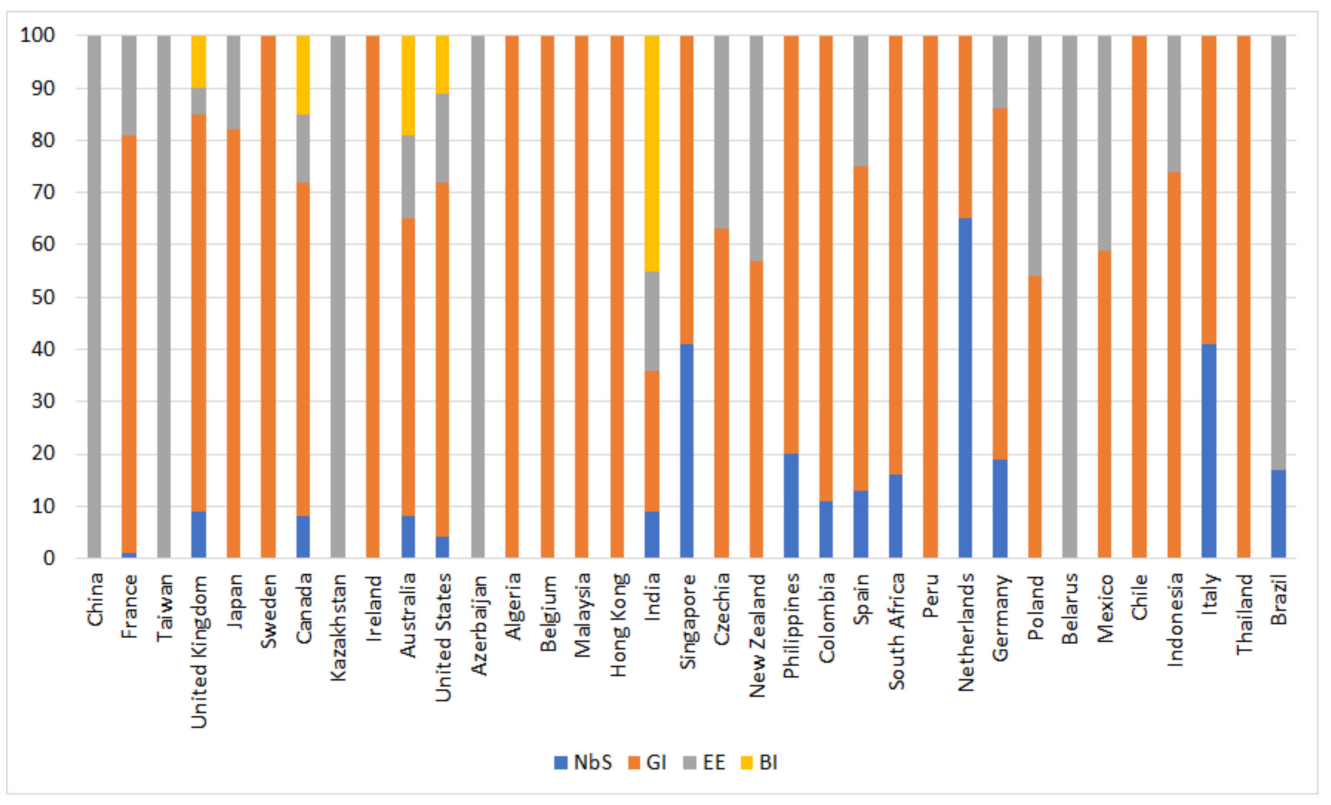

Figure 5. Interest by region of the terms ' $\mathrm{NbS}$ ', ' $\mathrm{GI}^{\prime},{ }^{\prime} \mathrm{BI}^{\prime}$, and ' $\mathrm{EE}$ '.

\section{The State-of-the-Art of the Nature-Based Solutions}

\subsection{Global Frameworks of NbS Governance}

3.1.1. Nature-Based Solutions within International Intra-Governmental and Non-Governmental Governance Frameworks

The realization and the opportunity for broader use of $\mathrm{NbS}$ by incorporating nature into a range of sectoral and overarching strategies to meet societal challenges, at the global scale, has grown significantly in recent years. The increasing recognition of $\mathrm{NbS}$ 's role in providing benefits to people is addressed in various international policy frameworks, such as the UN 2030 Agenda for Sustainable Development, the UN's Framework Convention on Climate Change (UNFCCC) and its Paris Agreement, the Ramsar Convention on Wetlands, the UN's Convention to Combat Desertification (UNCCD), and the Sendai Framework for DRR, etc.

According to IUCN, more than 130 countries have already included NbS actions (e.g., reforestation, GI, sustainable agriculture and aquaculture, and coastal protection) in their national climate plans under the Paris Agreement [18]. In the year of 2020, the IUCN and its Commission on Ecosystem Management (CEM) developed the Global Standard for $\mathrm{NbS}[18,36]$, which aimed to provide a foundation for the development of standards for implementing and upscaling $\mathrm{NbS}$ [10].

In addition to the $\mathrm{EbA} / \mathrm{EbM}$, the $\mathrm{NbS}$ have also been promoted in decisions of the UN CBD [57,58]. For example, in the year of 2019, in the Intergovernmental Science-Policy Platform on Biodiversity and Ecosystem Services (IPBES) Global Assessment report [59] and the UN CBD's Update of the Zero Draft of the Post-2020 Global Biodiversity Framework (GBF) in 2020 [60], the importance of recognizing and preserving nature's contribution to people as a key goal was addressed and $\mathrm{NbS}$ was seen as a key approach through which such goal can be achieved. Such an approach is also central to the CBD's mandate. Parties of the CBD promoted integration of $\mathrm{NbS}$ in the GBF as a pathway to achieving the 2030 action targets and ultimately the 2050 Vision [60].

Furthermore, the Sendai Framework for DRR called specifically for the development of standards for GI in order to stimulate investments in NbS [61]. Moreover, at the 2019 UN Climate Action Summit, NbS was one of the main topics discussed to combat climate change [62]. The role of strategic urban planning involving $\mathrm{NbS}$ is highlighted in both the EU-China and the EU-Latin American Partnership on Urbanization as well [63].

The UN New Urban Agenda makes specific reference to $\mathrm{NbS}$ for urban and territorial planning [64] and highlights the importance of biodiversity and the functioning 
of ecosystems to maintain economic activities and the well-being of local communities. Considering $\mathrm{NbS}$ as solutions can support biodiversity conservation and the functioning of ecosystems, manage water-related risks, and transform natural capital into a source of green growth and sustainable development; in this context, $\mathrm{NbS}$ has the potential to contribute to the 2030 Agenda for Sustainable Development's targets and to help achieve the SDGs by delivering simultaneously various ES, and generating different social, economic and environmental co-benefits [10,65]. According to several studies on the relation of $\mathrm{NbS}$ to the different SDGs [66-69], NbS are directly relevant to SDG 2 (food security), 3 (health and well-being), 6 (clean water and sanitation), 10 (reduce inequality), 11 (sustainable cities and communities), 13 (climate change), 14 (conservation and sustainable use of oceans, seas, and marine resources), and 15 (protection, restoration, and promotion of sustainable use of terrestrial ecosystems)

\subsubsection{Nature-Based Solutions within EU Research and Innovation Agenda}

The EU has played a leading role in the international mainstreaming of policies that innovate with nature and contribute specifically to implementing the UN 2030 Agenda for SDGs [70], and supporting the development and implementation of $\mathrm{NbS}$ on climate adaptation and mitigation, disaster risk reduction, biodiversity protection, health, and wellbeing improvement. $\mathrm{NbS}$ are included in the key priorities of the EU R\&I agenda. Since 2016, the EU has been supporting science-policy-business-society stakeholder dialogue platforms (such as ThinkNature) and promoting the market uptake of NbS. In 2017, as part of the Presidency of the Estonian Republic of the Council of the European Union, the "NbS: from innovation to common-use" conference was organized by the Ministry of the Environment of Estonia, focusing on policy and governance of $\mathrm{NbS}$.

Through EC's Community Research and Development Information Service (CORDIS) [71], with the keywords 'Nature-based solutions', we found out that until 18 May 2021 (the day we implemented this search), 52 projects with a total budget of 435 million EUR have been funded by the EU R\&I program since 2011 (Appendix A, Table A1). Table A1 provides an overview of the 52 projects which aim to create a community of practice/ecosystem on $\mathrm{NbS}$, including major calls, funding scheme, project overall budget, lead country and partner countries, scope, challenges addressed, and type of $\mathrm{NbS}$ developed or implemented.

To summarize, there are seven types of NbS projects/actions funded by the EU R\&I program (Table 2, Table A1; A detailed description of types of projects/actions can be found in the EC's General Annexes of the Main Work Program for Horizon 2020 [72], FP7 [73], and in the ERC Work Program [74]), including (i) coordination and support actions (CSA, 10 projects), such as "ThinkNature" and "NetworkNature" for multi-stakeholder dialogue platforms to promote NbS to societal challenges, "We Value Nature" and "MAIA" for mainstreaming natural capital in policies and in business decision-making, and "Eklipse" for focusing on method lies of knowledge learning mechanisms of biodiversity and ES; (ii) Research and innovation actions (RIA, 12 projects), e.g., projects "Nature4Cities" and "Naturvation" focusing on new governance, business, financing models, and economic assessment tools, project "NAIAD" for operationalizing insurance value of ecosystems, and projects "PONDERFUL", "DRYvER", "MaCoBioS", and "FutureMares" for inter-relations between climate change, biodiversity, and ES; (iii) Innovation actions (IA, 19 projects), e.g., projects on demonstrating innovation of $\mathrm{NbS}$ in cities (e.g., ConnectingNature, Grow Green, URBAN GreenUP, UNaLad, URBINAT, CLEVER Cities, proGIreg, EdiCitNet), projects on visionary and integrated solutions to improve well-being and health in cities (e.g., GO GREEN ROUTES, IN-HABIT, VARCITIES, EuPOLIS), and projects aiming to strengthen international cooperation on $\mathrm{NbS}$ for restoration and rehabilitation of urban ecosystems (e.g., CONEXUS, INTERLACE, REGREEN, CLEARING HOUSE); (iv) European Research Council-Networks (ERC-NET) cofunded actions (3 projects), such as "BiodivERsA" (78 sub-projects funded) on consolidating research about ES, biodiversity, and natural capital, and project "EN-SUGI" (15 sub-projects funded) on synthesizing the R\&I expertise and 
exploring innovative new solutions to the food-energy-water nexus challenge; (v) ERCSTG-Starting grants (1 project), e.g., the project Niche $4 \mathrm{NbS}$ aiming to offer the capability to predict and plan the best NbS implementation; (vi) Marie Skłodowska-Curie Actions Individual Fellowships (MSCA-IF, 3 projects), such as the project aiming to investigate childhood heat-related health impacts and protective effects of urban natural environments (e.g., Green CURIOCITY); and (vii) collaborative projects (CP, 4 projects), such as the project 'GREEN SURGE' proving a sound evidence base for GI planning and implementation, and linking environmental, social, and economic services with local communities.

Table 2. The type/funding scheme of nature-based solutions projects funded by the EU R\&I program (see Appendix A, Table A1).

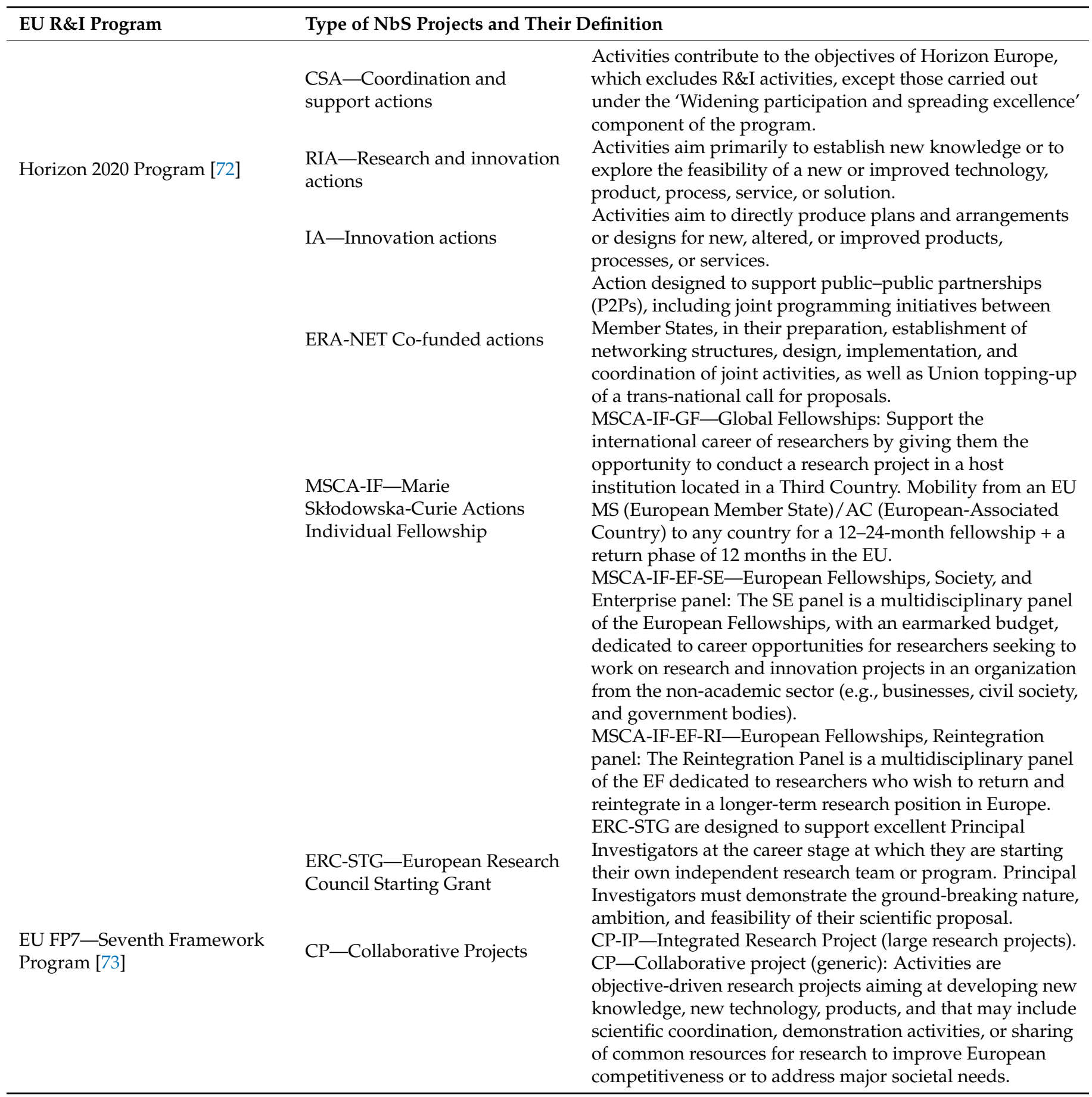


To summarize, the important principles in EU R\&I-funded NbS-related projects (Appendix A, Table A1) are: (i) innovation in terms of social, governance, technical, regulatory, business, and finance aspects; and (ii) addressing multiple challenges and applying codesign to co-management processes. The $\mathrm{NbS}$ as a topic certainly will not end with EU Horizon 2020. Further topics focused on NbS implementation and innovation are also included in EU Green Deal Calls [30], and Horizon Europe calls on cluster 3 ( $\mathrm{NbS}$ to enhance urban resilience and security (IA)), cluster 5 (Let nature do the job (RIA)), cluster 6 (Nature therapy (RIA), Socio-politics of NbS (RIA), Education for NbS (CSA), Economics of NbS (RIA), Network for nature (CSA), Agroecology and agroforestry (several topics)) [31], and other funding programs such as 'cohesion policy' funds [75], Invest EU [76], or LIFE program [77].

\subsubsection{Nature-Based Solutions within Chinese Governmental Framework}

In the field of $\mathrm{NbS}$, China has also carried out various explorations on approaches and practices, such as the ecological conservation redline system [78], local government heads as river chiefs and lake chiefs [79], international coalition for green development on the belt and road [80], natural forest protection, afforestation, and sustainable forest management [81], urban ecological restoration [82], and so on.

In September 2019, during the UN Climate Action Summit, China and New Zealand jointly took the lead for a NbS Coalition in promoting the work on NbS and identified $\mathrm{NbS}$ as an important global action [62]. In fact, NbS is aligned with China's "ecological civilization thought", the "harmony between man and nature" as described in the report of the 19th National Congress of the Communist Party of China, "lucid waters and lush mountains are invaluable assets", and "mountains, rivers, forests, fields, lakes and grasses form a community of shared life" [83,84].

It is worth mentioning that the Chinese 'Sponge City' initiatives are also quite in line with the NbS concept. The Chinese central government introduced the "Sponge City" concept in 2013 as an approach to tackle many water-related problems, such as flooding and water pollution. A city built on water-centered eco-infrastructure that act like sponges to retain rainwater and make use of natural forces to accumulate, infiltrate, and purify rainwater is called a "Sponge City" [85-87], which is totally opposite to the conventional solution of grey infrastructure [86]. The goal of China's Sponge City initiative is that by $2030,80 \%$ of urban areas should absorb and re-use at least 70\% of rainwater [88]. Since 2015, NbS for ecological "Sponge Cities" have been implemented at different scales in different Chinese cities, and include NbS such as terracing the slopes, building retention ponds and ponding the ground, dyking and ponding the swamps, islanding the lakes, restoration of wetlands and the floodplain, and the re-naturalization of the river course [89]. More than 600 cities in China are required to meet the Sponge City goals in the next decade [88].

\subsection{Implementation and Assessment of Nature-Based Solutions}

3.2.1. Type of Nature-Based Solutions Implemented

There are different ways to group the NbS and type of the NbS with different classification criteria. Table 3 summarizes the existing types of $\mathrm{NbS}$ with classification criteria and key references. 
Table 3. Type of nature-based solutions with their classification criteria and key references.

$\begin{array}{lll}\text { Type of Nature-Based Solutions } & \begin{array}{l}\text { Classification } \\ \text { Criteria }\end{array} & \text { Key References }\end{array}$

(1) Solutions that involve making better use of existing natural or protected ecosystems (e.g., measures to increase fish stocks in an intact wetland to enhance food security).

(2) Solutions based on developing sustainable management protocols and procedures for managed or restored ecosystems (e.g., re-establishing traditional agro-forestry systems based on commercial tree species

Degree of $\mathrm{NbS}$

interventions

$[90,91]$

(3) Solutions that involve creating new ecosystems (e.g., establishing green buildings, such as green walls and green roofs).

(1) Better use of protected/natural ecosystems, e.g., protection and conservation strategies in terrestrial (e.g., Natura 2000—a network of nature protection areas in the territory of the European Union), marine (e.g., marine protected area), and coastal areas (e.g., mangroves) ecosystems.

(2) NbS for sustainability and multifunctionality of managed ecosystems, such as agricultural landscape management, coastal landscape management, extensive urban green space management, and monitoring.

(3) Design and management of new ecosystems, for example, intensive urban green space management, urban planning strategies, urban water management, ecological restoration of degraded terrestrial ecosystems, restoration and creation of semi-natural water bodies and hydrographic networks, and ecological restoration of degraded coastal and marine ecosystems.

The degree of intervention/level and type of engineering in many (sub)categories

(1) Greening interventions

(2) Public green space

(3) Vertical greening

(4) Green roofs

(5) Water-sensitive urban design measure

(6) River restoration

$\mathrm{NbS}$ planning and construction terminology

(7) Measure of bioengineering

(8) Other $\mathrm{NbS}$
(1) Green NbS
(2) Blue NbS
(3) Hybrid $\mathrm{NbS}$

Type of engineering, the type of ecosystem, and ecosystem functions

52 EU-funded projects (Table A1) level. 
To summarize, at the engineering and ecosystem functions level, the NbS projects' websites and applications (Appendix A, Table A1) can be divided into three main approaches: (1) green (e.g., parks, forests), (2) blue (e.g., rivers, channels, lakes, ponds), and (3) hybrid (e.g., combining green/blue or blue/green and grey infrastructure approaches). Of the 52 projects websites/applications reviewed in Europe (Appendix A, Table A1), 22 were developed for or tested the green type of $\mathrm{NbS}, 18$ were developed for or tested the blue type of $\mathrm{NbS}$, and 33 were developed for or tested the hybrid type of NbS. Therefore, most sites/applications were focused on hybrid types of $\mathrm{NbS}$.

3.2.2. Challenges Addressed by the Nature-Based Solutions and Their Key Performance Indicators for Impacts Assessment

$\mathrm{NbS}$ refers to the sustainable management and use of nature for tackling various challenges. In this study, such challenges are further categorized into three groups, including: (i) environmental challenges (e.g., climate change, urban sprawl, ecosystem degradation, soil sealing, landslides, heat stress, drought, storm surges, flooding, noise, environmental quality in public spaces, lack of green spaces, air pollution, biodiversity loss, water pollution, and food security) [93-101], (ii) economic challenges (e.g., lack of community capital, economic decline, employment issues, inefficient resource management, productivity, and affordability issues) [27,102], and (iii) social challenges (e.g., human health, quality of life, public participation, and equity) $[27,102]$.

Moreover, there is a range of KPIs that have been developed to measure the impact of $\mathrm{NbS}$ or challenges addressed [92]. To acquire an overview of KPIs for NbS impact assessment, in addition to reviewing 52 EU-funded projects, for key relevant publications, we used the keywords 'nature-based solutions' and 'impact assessment' in Google Scholar and reviewed 33 articles in total (see key references column in Appendix B, Table A2). Appendix B, Table A2 provides a brief overview of existing indicators that have been developed and methodologies used to assess various NbS's impacts on the environment, economy, and society, respectively.

Of the 52 projects' websites/applications reviewed in Europe (Appendix A, Table A1), a majority of the projects focused on challenges related to urbanization, climate change and its implications for the environment, human health, and well-being. To summarize, the main challenges addressed by these 52 projects are climate change, air pollution, greenhouse gases (GHG) emissions, biodiversity loss, ES degradation, marine coastal ecosystem degradation, drying rivers, flooding, soil erosion, landslides, drought, heat stress, drinking water consumption, energy consumption, lack of adequate GI, lack of quality greenspaces, limited natural ecosystems, landscape fragmentation, and urban sprawl. Accordingly, the key impacts assessed by these projects are climate resilience and mitigation, biodiversity enhancement, microclimate regulation and air quality improvement, flood mitigation and coastal resilience, improving water quality and waterbody conditions, sustainable communities, innovative governance, and business models. For completed projects, most focus solely on environmental benefits delivered by NbS, and only very few have looked at economic benefits of $\mathrm{NbS}$ and their contribution to reducing social injustice and improving social capacity building and cohesion (ECLIPSE, ThinkNature, and NAIAD). However, several ongoing and newly funded projects (e.g., REGREEN, UrbiNAt, EdiCitNet, ProGIreg, CleverCities, Grow Green, Connecting Nature, NATURVATION, and Nature4Cities) have highlighted the necessity to assess NbS's impact on social justice and social cohesion, new economic opportunities, and green jobs.

\subsubsection{Nature-Based Solutions Data and Metadata}

As of July 2021, there are several databases and platforms focusing on $\mathrm{NbS}$ and their related environmental topics, which allow the users to share knowledge and experience, and combine and use data and information at national, regional, and global levels. For example, the ThinkNature platform [17,103], Oppla-EU Repository of NbS [19], NbS initiative [104], and Urban Nature Atlas [105] are platforms on diverse environmental challenges directly addressed by NbS, while the European Environmental Agency (EEA) 
Data and Maps [106], EEA Climate-ADAPT [107], EU Joint Research Centre (JRC) Data Catalogue [108], Copernicus-Europe's Eye on Earth [109], EU Biodiversity Information System [110], EU water information system [111], and EU forest information system [112] are databases and platforms which have systematically collected diverse data, including data on specific natural hazards, that may not be directly related to $\mathrm{NbS}$, but can be useful when designing and implementing $\mathrm{NbS}$, for example, certain type of hazards can be mitigated or resolved by NbS. Table 4 summarizes the selected $\mathrm{NbS}$ databases and platforms with their brands and brief descriptions.

Table 4. Selected nature-based solutions databases and platforms.

\begin{tabular}{|c|c|c|}
\hline Database/Platform & Brand & Description \\
\hline ThinkNature & $\begin{array}{l}\text { A multi-stakeholder } \\
\text { communication platform [103] }\end{array}$ & $\begin{array}{l}\text { Supporting the understanding and promotion of } \\
\text { NbS. }\end{array}$ \\
\hline Oppla & $\begin{array}{l}\text { Open platform that hosts the } \\
\text { EU Repository of NbS [19] }\end{array}$ & $\begin{array}{l}\text { The EU Repository of NbS, which provides a } \\
\text { knowledge marketplace, where the latest thinking } \\
\text { on natural capital, ecosystem services, and NbS is } \\
\text { brought together. }\end{array}$ \\
\hline $\mathrm{NbS}$ initiative & Interdisciplinary program [104] & $\begin{array}{l}\text { NbS initiative is an interdisciplinary program, } \\
\text { seeking to apply impactful research to shape policy } \\
\text { and practice on NbS through research, teaching, and } \\
\text { engagement with policymakers and practitioners. }\end{array}$ \\
\hline Urban Nature Atlas & Atlas [105] & $\begin{array}{l}\text { It contains } 1000 \text { examples of } \mathrm{NbS} \text { from across } 100 \\
\text { European cities. } \\
\text { It supports Europe in adapting to climate change } \\
\text { and in helping users to access and share data and } \\
\text { information on: }\end{array}$ \\
\hline Climate-ADAPT & $\begin{array}{l}\text { European Climate Adaptation } \\
\text { Platform [107] }\end{array}$ & $\begin{array}{l}\text { - } \quad \text { Expected climate change in Europe } \\
\text { - } \quad \text { anrent and future vulnerability of regions } \\
\text { and sectors } \\
\text { EU, national, and transnational adaptation } \\
\text { strategies, and actions } \\
\text { - Adaptation case studies and potential } \\
\text { adaptation options including NbS } \\
\text { Tools that support adaptation planning }\end{array}$ \\
\hline EEA Data and Maps & $\begin{array}{l}\text { EEA Data and Maps provides } \\
\text { access to datasets used in } \\
\text { EEA periodical reports [106] }\end{array}$ & 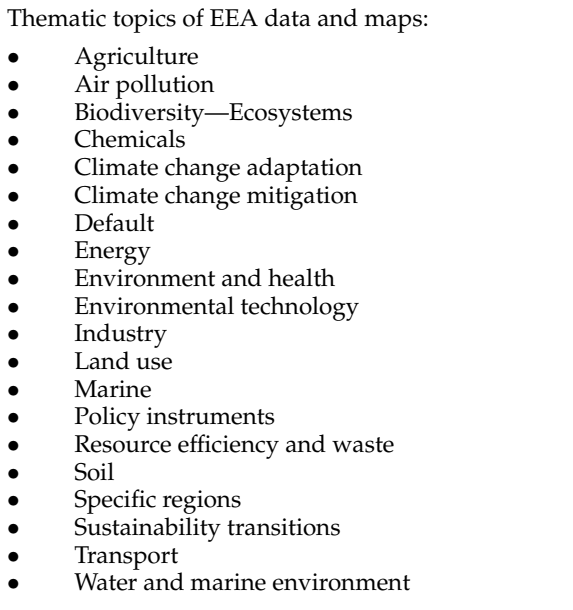 \\
\hline JRC Data Catalogue & $\begin{array}{l}\text { The JRC Data Catalogue } \\
\text { provides access to the } \\
\text { multidisciplinary data } \\
\text { produced and maintained by } \\
\text { the JRC [108] }\end{array}$ & $\begin{array}{l}\text { Thematic scope of JRC data catalogue: } \\
\text { - } \quad \text { Environment and climate change } \\
\text { - } \quad \text { Agriculture and food Security } \\
\text { - } \quad \text { Economic and monetary union } \\
\text { - } \quad \text { Health and transport } \\
\text { - Information society } \\
\text { - } \quad \text { Innovation and growth } \\
\text { - } \quad \text { Suclear safety and security } \\
\text { - Stety and security } \\
\quad \text { Standards }\end{array}$ \\
\hline
\end{tabular}


Table 4. Cont.

\begin{tabular}{|c|c|c|}
\hline Database/Platform & Brand & Description \\
\hline & & $\begin{array}{l}\text { It is the European system for monitoring the Earth and is } \\
\text { coordinated and managed by the EC. Its services address six } \\
\text { thematic areas: }\end{array}$ \\
\hline Copernicus & $\begin{array}{l}\text { The European Earth } \\
\text { Observation Program } \\
\text { [109] }\end{array}$ & $\begin{array}{ll}- & \text { Land } \\
- & \text { Marine } \\
- & \text { Atmosphere } \\
- & \text { Climate change } \\
- & \text { Emergency management } \\
- & \text { Security }\end{array}$ \\
\hline $\begin{array}{l}\text { BISE-Biodiversity } \\
\text { Information System for } \\
\text { Europe }\end{array}$ & $\begin{array}{l}\text { The source of data and } \\
\text { information on } \\
\text { biodiversity in Europe } \\
\text { [110] }\end{array}$ & $\begin{array}{l}\text { It is a single-entry point for data and information on } \\
\text { biodiversity supporting the implementation of the EU } \\
\text { strategy and the Aichi targets in Europe. }\end{array}$ \\
\hline $\begin{array}{l}\text { WISE-Water Information } \\
\text { System for Europe }\end{array}$ & $\begin{array}{l}\text { European information } \\
\text { gateway to water issues } \\
{[111]}\end{array}$ & $\begin{array}{l}\text { It is a joint initiative from the EC (DG Environment, JRC, and } \\
\text { Eurostat) and the EEA to modernize and streamline the } \\
\text { collection and dissemination of information related to } \\
\text { European water policy. }\end{array}$ \\
\hline $\begin{array}{l}\text { FISE-Forest information } \\
\text { system for Europe }\end{array}$ & $\begin{array}{l}\text { The entry point for } \\
\text { sharing information with } \\
\text { the forest community on } \\
\text { Europe's forest } \\
\text { environment, its state, and } \\
\text { development [112] }\end{array}$ & $\begin{array}{l}\text { It brings data, information, and knowledge gathered or } \\
\text { derived through key forest-related policy drivers. }\end{array}$ \\
\hline
\end{tabular}

3.2.4. Stakeholders' and Citizens' Prioritization for Nature-Based Solutions Implementation

Stakeholder and citizen participation and collaboration in $\mathrm{NbS}$ are increasingly recognized as promising [113]. However, there are different prioritizations for different beneficiaries. For example, for general citizens, NbS need to be aesthetically appealing [114]. For urban planners, they need to have an open approach to collaborative governance of $\mathrm{NbS}$ that allows learning with and about new attractive designs, perceptions, and images of nature from different urban actors, and allows forming new institutions for operating and maintaining $\mathrm{NbS}$ to ensure inclusivity, livability, and resilience [114].

Of the 52 projects websites/applications reviewed in Europe (Appendix A, Table A1), a majority of $\mathrm{NbS}$ were typically implemented in cities on a small scale to target specific types of challenges, particularly linking to urbanization and climate change and its implications for environment and society, such as projects on water and climate resilience (Connecting Nature, Grow Green, Urban GreenUP, UNaLab), inclusive urban regeneration (CLEVER Cities, EdiCitNet, ProgIreg, URBINAT), decarbonization and air quality (DivAirCity, Upsurge, JUSTNature), improving health and well-being (EUPOLIS, GO GREEN ROUTES, IN-HABIT, VARCITIES), governance-business-financing models and economic impact assessment tools (NATURVATION, Nature4cities), restoration and rehabilitation of urban ecosystems (CLEARING HOUSE, REGREEN, CONEXUS, INTERLACE), inter-relationship between climate change, biodiversity, and ES (DRYvER, FutureMARES, MaCoBioS, PONDERFUL), and insurance value of ecosystems (NAIAD). Only a small number of projects (OPERANDUM, PHUSICOS, RECONECT) implemented NbS in rural and mountainous areas at a relatively large scale and targeted the challenges related to hydro-meteorological hazards, particularly, e.g., extreme weather events, flooding, erosion, landslides, and drought. This may be due to the challenges of the NbS implementation, cost, and governance at large scales. However, there is a lot of work going on at the moment under the umbrella of re-wilding [115]. Re-wilding is now a widespread approach across Europe that has some different aims, but with some overlap through common aims with $\mathrm{NbS}$ in terms of promoting better ES provision, for instance re-wilding of certain mountainous areas can support soil stability and prevent excessive runoff, leading to reduced flood impacts and landslide risk [116]. 


\section{Discussion}

\subsection{Nature-Based Solutions as a Strong Concept That Is Becoming Recognized and Accepted}

$\mathrm{NbS}$ is a term that is defined and used differently by a number of stakeholders. Until now, the IUCN and the EC have developed their own definitions of $\mathrm{NbS}$, which while broadly similar have different focuses, for example, they share the overall goal of addressing major societal challenges through the effective use of ecosystem and ES (See Section 2.1). The IUCN's definition was developed from a global perspective and emphasizes the need for a well-managed or restored ecosystem to be at the heart of any $\mathrm{NbS}$, while the EC definition places more emphasis on applying solutions that not only use nature but are also inspired and supported by nature [117]. The IUCN [27] (p. 10) proposed to consider " $\mathrm{NbS}$ as an umbrella concept, which covered ecosystem-based management and issue-specific ecosystem related approaches (e.g., EbA/EbM, ecosystem-based disaster risk reduction), infrastructure-related approaches (e.g., GI, BI, BGI/GBI), and ecosystem protection approaches (e.g., EbA)". The EC suggested that the "NbS builds on and supports other closely related concepts, such as the EE, ES, EbA/EbM, GI and BI" [9] (p. 24). Both the IUCN and the EC emphasize $\mathrm{NbS}$ as concrete actions that cover a range of ecosystem-related approaches to solve problems at a local and regional scale [118].

Although there is no unified definition of $\mathrm{NbS}$, the concept of $\mathrm{NbS}$ links the multiple potential positive outcomes for society. In fact, it is not a problem that there is a lack of a unified definition of $\mathrm{NbS}$. The existing concepts of $\mathrm{NbS}$ cover a broad range of aspects dealing with the challenges of our time, e.g., biodiversity loss, climate crisis, and the need for building resilient futures for societies in urban, rural, and wild landscapes for healthy people and a healthy nature. $\mathrm{NbS}$ could as such be considered as an overarching concept for all related terms, which is in line with Lafortezza et al. [119] and Davies et al. [120] addressment in a European context. In addition, from an impact perspective, the $\mathrm{NbS}$ concept can be seen to encompass existing concepts such as EbA/EbM, as proposed by Rizvi et al. [121]. Furthermore, NbS can be used to build GI, BI, and BGI/GBI, but GI, BI, and BGI/GBI can also be part of a broader NbS infrastructure, as addressed by Balian et al. [122] (See Section 2.2).

The increasing use of the $\mathrm{NbS}$ concept in the literature shows the growing interest of the scientific community in using $\mathrm{NbS}$ as an overarching framework, on how to use nature to address multiple challenges and foster sustainability (See Section 2.3). On the other hand, globally, of the $\mathrm{NbS}$ concept remains less used in non-scientific discourses, but still gaining more and more interest since 2016, when the term ' $\mathrm{NbS}$ ' was coined by the EC (See Section 2.4). With a disparate geographical anchor, $\mathrm{NbS}$ is in high usage, especially in some Western European countries. These trends of non-scientific use of NbS are also aligned with the scientific mapping of $\mathrm{NbS}$ in urbanism performed by Li et al. [123]. NbS is much less common than the GI concept in general when considering non-scientific search engines such as Google Trends (see Section 2.4), which is not very surprising given that NbS is a relatively new phrase. To the best of our knowledge, no study has been carried out on analyzing the emergence of $\mathrm{NbS}$ and the related concepts over time in broader discourses towards more layman outlets, and the geographical coverage for the different NbS-related concepts. Such type of analysis is quite important in terms of awareness raising of $\mathrm{NbS}$ concepts, broad participation in developing a $\mathrm{NbS}$, successful implementation of $\mathrm{NbS}$, etc., which are aligned well with the IUCN's NbS core principles, in particular principle 3 (NbS are determined by site-specific natural and culture contexts that include traditional, local, and scientific knowledge), and 4 (NbS produce society benefits in a fair and equitable way in a manner that promotes transparency and broad participation) [10].

\subsection{Need for Good Practices of Implementation and Stronger Evidence of the Benefits of Nature-Based Solutions to Tackle Environment, Health, and Well-Being Challenges}

$\mathrm{NbS}$ can be applied strategically and equitably to help societies address a variety of climatic and non-climatic challenges. Based upon the review of $52 \mathrm{NbS}$ projects' websites/applications (Appendix A, Table A1) and some relevant publications, the key areas 
for $\mathrm{NbS}$ practices and evidence developed are biodiversity, climate change mitigation and adaptation (including flooding), water quality, air quality and microclimate, sustainable communities, innovative governance and business models, and market challenges and solutions [124]. NbS can provide low-risk, low-maintenance, and low-cost solutions to climate change-related hazards and impacts $[125,126]$, but there is still a lack of understanding on how best to implement them in practice, in an up-scaled manner, and on how to strengthen integration within institutions. Several studies identified the challenges to implement $\mathrm{NbS}$ in the future planning and management of green/blue landscape and to include institutional changes (e.g., policy, governance, and culture) for future refinements of the NbS concept and its applications in both rural and urban landscapes $[9,127,128]$. The EU-funded project ThinkNature addressed that NbS are energy- and resource-efficient, and resilient to change, but to be successful, they must be adapted to local conditions [17] (Appendix A, Table A1), which is also recognized by the IUCN[129,130].

The IUCN addressed three major challenges for NbS implementation and its impact evaluation [130]. First, challenges in measuring or predicting the effectiveness of NbS lead to high uncertainty about their cost-effectiveness compared to alternatives, which is also well-reflected by very few projects funded by the EC on assessing cost-effectiveness and cost-economic benefits (e.g., ECLIPSE, ThinkNature, and NAIAD, see Appendix A, Table A1). Second, poor financial models and flawed approaches to economic appraisal led to underinvestment in $\mathrm{NbS}$. Third, inflexible and highly sectorized forms of governance hinder uptake of $\mathrm{NbS}$, where grey and engineered interventions are still the default approach for climate adaptation and mitigation challenges. Such challenges on participatory planning and governance are also highlighted by several EU-funded NbS projects, such as ThinkNature, CONNECTING NATURE, UNaLab, URBAN GreenUP, and CLEVER Cities [92] (see Appendix A, Table A1).

NbS has wide applications in environment, society, and economy, but in fact, it is quite difficult to assess its impact on environmental-social-economic benefits together, which is well-reflected by the few studies that have assessed or are aiming to assess simultaneously social, economic, and environmental benefits (i.e., OpenNESS, EKLIPSE, GREEN SURGE) [69]. Within the 52 projects and some other relevant publications reviewed, the environmental research fields dominate use and interpretation of the $\mathrm{NbS}$ in practices, which is aligned well with the results highlighted by Hanson et al. in their study on 'Working on the boundaries-how does science use and interpret the NbS concept' [69]. Therefore, there is a need for stronger evidence of the benefits of $\mathrm{NbS}$ to tackle environmental, health, and well-being challenges simultaneously. To do so, it is important to understand the value and limits of $\mathrm{NbS}$, such as $\mathrm{NbS}^{\prime}$ s reliability and its cost-effectiveness by comparing it to greyengineered interventions, and $\mathrm{NbS}^{\prime} \mathrm{s}$ resilience to climate change and its co-benefits and trade-offs. For example, benefits in one challenge area (e.g., green infrastructure) can have co-benefits, costs, or neutral effects in other challenge areas (e.g., improvement of place attractiveness, health and well-being, creation of green jobs) [131]. Trade-offs can arise if climate mitigation policy encourages $\mathrm{NbS}$ with low biodiversity value, such as afforestation with non-native monocultures, which can result in maladaptation, particularly in the regions where biodiversity-based resilience and multi-functional landscapes are the key [129]. Therefore, the challenges addressed by the NbS and its environmental-social-economic benefits will not be realized unless they are implemented within a system-thinking framework that accounts for multiple ES and recognizes trade-offs and synergies among them from the perspective of different stakeholders [129].

Moreover, it is challenging to assess $\mathrm{NbS}$ using a multitude of sensors and data sources, including remotely sensed images (e.g., high-resolution satellite sensors, field sensors, and airborne LiDAR) and field data [132], and scale-up NbS benefits to the global level and provide evidence metrics or indicators that managers and policymakers can easily access and use [119]. Hunt et al. [133] addressed the need for stronger evidence of the benefits of nature to tackle the problem of dementia. Lafortezza et al. [119] addressed the challenges to understand the linkages between $\mathrm{NbS}$ and associated $\mathrm{ES}$ within the four main categories 
of provisioning, regulating, cultural, and supporting across different scales (e.g., from the "core" urban area to the wider peri-urban landscape). NbS benefits will not be released unless they are implemented within a systems-thinking framework that fully accounts for their potential to support multiple ES and the trade-offs among them $[68,130]$.

\subsection{Need for Sustainable Design of Nature-Based Solutions}

There are several aspects that need to be considered for sustainable design and codesign of NbS. Based upon the review of 52 EU-funded projects and some relevant publications (Sections 3.2.1, 3.2.2 and 3.2.4, Appendix A, Table A1), the following aspects of $\mathrm{NbS}$ shall be addressed. First, the scope and nature of the problems that need to be solved shall be defined $[7,27,134]$, including many aspects, such as: (i) Are these problems short-lived, long-lasting, or permanent? (ii) Who are the stakeholders? and (iii) What are the potential difficulties in the solution?

Secondly, nature's boundaries, i.e., the aspects related to the biological and abiotic composition of the ecosystem, should be considered [7,27,134], such as: (i) Can an ecosystem be considered as a whole, including water, material circulation, and energy flow? (ii) Can landscape and urban environment with artificial structure and human beings be included? and (iii) Can an ecosystem's self-sustaining potential be regarded as an aspect of natural attributes and sustainability? Most $\mathrm{NbS}$ have an impact on the ecosystem composition, functionalities, and features to some extent, e.g., while selecting certain ES and certain species combinations. This also means that there will be trade-offs that must be evaluated. This is a matter of multiple complexity. For example, restoration of a wetland for flood control may have a positive impact on a variety of ES, such as climate regulation, water purification, and provision of habitat and ecotourism. However, at the same time, it will have a negative impact on local agricultural production, which is a trade-off [134].

Third, the participation of multiple stakeholders (e.g., financiers, planners, designers, and innovators) and their creative dialogue shall be ensured, as addressed by EU-funded projects "ReNature", "NBS2017", and "CLEVER Cities" (Appendix A, Table A1). To realize the multi-stakeholder participation, the following questions shall be discussed, including: (i) Do these solutions rely on technological or physical innovation? and (ii) How to ensure social cohesion and fairness and how to judge the fairness? In most cases, key decisions about $\mathrm{NbS}$ design, cost, location, size, and the level of management intensity will involve a wide range of stakeholders, who may have different ideas and ways of managing these issues $[7,134]$. Then, it is necessary to ensure the participation of multiple stakeholders, since their views, considerations, and knowledge can provide information for planning and improve the planning. The participation of stakeholders will increase the adequacy and legitimacy of a $\mathrm{NbS}$.

Fourth, NbS projects also need to be integrated with multidisciplinary and interdisciplinary fields, as addressed by the project "ReNature" (Appendix A, Table A1). In fact, in many restoration and rehabilitation projects, close cooperation is needed among ecological science, engineering, and social science, to jointly deal with the problem of how to provide ES $[7,134]$. With the development of $\mathrm{NbS}$, there may be more demands for interdisciplinary and multidisciplinary integration to foster trans-disciplinarity. Moreover, as an ambitious policy instrument, $\mathrm{NbS}$ needs strategic design. Large-scale $\mathrm{NbS}$ will require several years or even decades of management. If the political situation or political agenda changes too often, it is difficult to ensure the effective implementation of long-term $\mathrm{NbS}$. Therefore, it is necessary to maintain the stability of the policy, which will require a broad consensus among political parties on the $\mathrm{NbS}$ policy.

\section{Conclusions}

This paper analyzed $\mathrm{NbS}$ and the related concepts, including the Chinese Sponge City concept, investigated the global frameworks of $\mathrm{NbS}$ governance, and addressed NbS's benefits, challenges, and development needs for its implementation and assessment. 
Based on the $52 \mathrm{NbS}$ projects' review and synthesis presented, and the discussion above, we conclude the following:

(1) NbS and its related concepts: There is a common understanding and increasing recognition that $\mathrm{NbS}$ are valid solutions for securing ES and improving environmental quality while bringing important health, and well-being benefits. NbS has been broadly promoted by the IUCN and the EC as living solutions and actions to tackle various societal challenges. The concept of $\mathrm{NbS}$ is aligned very well with the concepts of EE, BI, GI, GBI/BGI, EbA/EbM, and the Chinese 'Sponge City' concept.

(2) Emergence and frequency of $\mathrm{NbS}$ over time and its geographical coverage: There is a growing interest of the scientific community in using $\mathrm{NbS}$. NbS concept remains less used in non-scientific discourses, but they are still gaining more and more interest. There is a disparate geographical anchor of $\mathrm{NbS}$. NbS is mainly used in Western European countries, such as the Netherlands, the UK, and Switzerland.

(3) NbS categorization: The challenges addressed by the NbS and the KPIs used to assess $\mathrm{NbS}$ impacts can be categorized in different ways. In this study, we grouped the challenges addressed by the NbS into environmental, economic, and social aspects; accordingly, we grouped the NbS impacts and the KPIs to assess the impact into environmental, economic, and social impacts as well. There are also different ways to categorize the type of $\mathrm{NbS}$. In this study, we divided NbS into three types with different classification criteria, i.e., green, blue, and hybrid NbS. Most NbS implemented in Europe were focused on hybrid types of $\mathrm{NbS}$.

(4) NbS implementation and assessment: The majority of NbS implemented in Europe are at the city level, and on relatively small scales to target challenges particularly linked to urbanization and climate change and their implications for the environment and society. Only a small number of NbS are implemented in rural and mountainous areas, at relatively large scales, and target the challenges related to hydro-meteorological hazards. Additionally, only a few projects have looked at the economic benefits of $\mathrm{NbS}$ and their contribution to reducing social injustice and improving social capacity building and cohesion. There are concerns over $\mathrm{NbS}^{\prime}$ s reliability and cost-effectiveness compared to grey-engineered alternatives. There is a need for more research on beneficiaries in $\mathrm{NbS}$ evaluation, particularly economic benefits and contribution to social justice, social cohesion, new economic opportunities, and green jobs.

(5) NbS data and metadata platforms: There are several existing NbS-related data and metadata platforms, including platforms in which environmental challenges can be addressed directly by NbS, such as ThinkNature, Oppla, NbS initiative, and Urban Nature. There are also platforms that have collected diverse data, which may not be directly related to $\mathrm{NbS}$, but can be useful when designing and implementing $\mathrm{NbS}$, such as EEA Data and Maps, EEA Climate-ADAPT, JRC Data Catalogue, EU Copernicus, EU Biodiversity Information System, EU water information system, and EU forest information system.

(6) NbS benefits and challenges of implementation and assessment: There is a great amount of evidence for $\mathrm{NbS}$ benefits for restoration and rehabilitation of ecosystems, carbon neutrality, and improved environmental quality, eventually improving health and well-being. However, the mechanism of NbS provision of the intended benefits, especially of combined multiple benefits of one and several $\mathrm{NbS}$, still need to be better understood; especially, co-benefits, synergies, and trade-offs have not been systematically measured in diverse structures, configuration, and scale.

There is a lack of recommendations of optimal $\mathrm{NbS}$ and appropriate typologies fitting to different contexts in terms of different climatic, environmental, and social-economic conditions and different urban design. Although tools, models, design guidelines, standards, and protocols exist, there is still a need for an integrated and system-thinking framework for NbS implementation and impact evaluation, that integrates NbS into local policy frameworks, socio-economic transition pathways, and spatial planning. Filling these knowledge and evidence gaps will make strong cases for wide deployment and success- 
ful implementation of $\mathrm{NbS}$. NbS also require co-creation and co-management settings to connect with urban social innovation, and a collaborative approach to their planning and implementation. It is important to see the innovative forces at work when planning $\mathrm{NbS}$ and the need to bring the scientific community, the private sector, and the policymakers together. The financial and governance challenges are the major barriers to implementing $\mathrm{NbS}$ at scale. Reform in governments is required to allow desilofication and more flexible urban governance structures and to support collaborative bottom-up processes, such as grass root and civil society initiatives. For businesses, it is necessary to make the financial case for $\mathrm{NbS}$, synthesizing the existing practices on sustainable and innovative financing of $\mathrm{NbS}$, bringing actors of social innovations together, and developing promotional strategies and business models.

Author Contributions: H.-Y.L. initiated the study, undertook the review of NbS projects and other relevant publications, wrote the draft, and led the revisions of the manuscript; M.J. and X.C. wrote part of the manuscript, contributed to the refinement of the core idea of the study, and participated in the revisions of the manuscript. All authors have read and agreed to the published version of the manuscript.

Funding: This research received no external funding.

Institutional Review Board Statement: Not applicable.

Informed Consent Statement: Not applicable.

Data Availability Statement: Not applicable.

Acknowledgments: Open-access publication was funded by NILU—Norwegian Institute for Air Research. Liu received funding from the NILU-NIVA SIS project on urban sustainable development, EEA ETC/CME and ETC/ATNI tasks on urban environmental sustainability, and NILU internal project on nature-based solutions for improving environmental quality, health, and well-being. We would like to thank the anonymous referees for their very valuable comments. Special thanks to Paul D. Hamer, at the Urban Environment and Industry Department (NILU), for helping us with the language. Any remaining errors are the responsibility of the authors.

Conflicts of Interest: The authors declare no conflict of interest. 


\section{Appendix A}

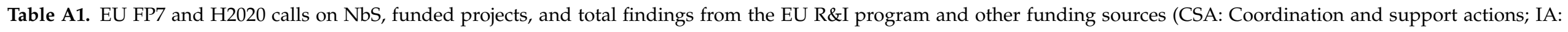

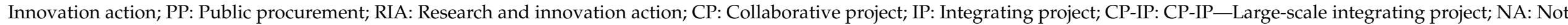
applicable/Not available).

\begin{tabular}{|c|c|c|c|c|c|c|c|c|}
\hline & $\begin{array}{l}\text { Type of } \\
\text { Call/Funding } \\
\text { Scheme }\end{array}$ & $\begin{array}{l}\text { Funded } \\
\text { Projects/Duration/Scope/Web } \\
\text { Portal }\end{array}$ & Budget $(€)$ & $\begin{array}{l}\text { Lead Coun- } \\
\text { try/Partners } \\
\text { Countries/No. } \\
\text { of Partners }\end{array}$ & $\begin{array}{l}\text { Study } \\
\text { Area/Scale }\end{array}$ & $\begin{array}{l}\text { Challenged } \\
\text { Addressed }\end{array}$ & $\begin{array}{l}\text { NbS-Related } \\
\text { Concept }\end{array}$ & $\begin{array}{l}\text { Type of NbS De- } \\
\text { veloped/Tested }\end{array}$ \\
\hline $\begin{array}{l}\text { ENV.2011.2.1.5-1- } \\
\text { Sustainable and } \\
\text { Resilient Green } \\
\text { Cities }\end{array}$ & CP-IP & $\begin{array}{l}\text { TURAS-Urban resilience and } \\
\text { sustainability (2011-2016): test the } \\
\text { feasibility of urban sustainable } \\
\text { transition approaches in selected case } \\
\text { study neighborhoods to enable } \\
\text { adaptive governance, collaborative } \\
\text { decision-making, and behavioral } \\
\text { change towards resilient and } \\
\text { sustainable European cities. } \\
\text { https: / / cordis.europa.eu/project/ } \\
\text { id/282834 (accessed on } 28 \text { September } \\
\text { 2021)http:/ /r1.zotoi.com (accessed } \\
\text { on 28 June 2021) }\end{array}$ & $8,869,491$ & $\begin{array}{l}\text { IE/UK, NL, RS, } \\
\text { DK, DE, BG, SI, } \\
\text { IT, BE, ES, IE/33 } \\
\text { partners (11 } \\
\text { countries) }\end{array}$ & Europe & $\begin{array}{l}\text { Climate } \\
\text { change } \\
\text { Natural } \\
\text { resource } \\
\text { shortage } \\
\text { Unprecedented } \\
\text { urban growth }\end{array}$ & GI & $\begin{array}{l}\text { Green (e.g., } \\
\text { renaturing the city, } \\
\text { green roofs, green } \\
\text { living room, } \\
\text { pocket park, } \\
\text { agriculture land, } \\
\text { landscape park, } \\
\text { urban gardens) }\end{array}$ \\
\hline $\begin{array}{l}\text { ENV.2012.6.2-1- } \\
\text { Exploration of the } \\
\text { operational } \\
\text { potential of the } \\
\text { concepts of } \\
\text { ecosystem services } \\
\text { and natural capital } \\
\text { to systematically } \\
\text { inform sustainable } \\
\text { land, water, and } \\
\text { urban } \\
\text { management }\end{array}$ & $\mathrm{CP}$ & $\begin{array}{l}\text { OPERAS-Ecosystem science for } \\
\text { policy \& practice (2012-2017): apply } \\
\text { the ecosystem services and natural } \\
\text { capital concept into practice. https: / / } \\
\text { cordis.europa.eu/project/id/308393 } \\
\text { (accessed on } 28 \text { June 2021) } \\
\text { http:/ / operas-project.eu (accessed } \\
\text { on } 28 \text { June 2021) }\end{array}$ & $11,459,749$ & $\begin{array}{l}\text { UK/NL, DE, SE, } \\
\text { FI, BE, UK, RO, } \\
\text { IE, FR, CH, BG, } \\
\text { ES, PT, ES, } \\
\text { ID } / 29 \text { partners } \\
\text { (15 countries) }\end{array}$ & $\begin{array}{l}\text { Europe and } \\
\text { Indonesia }\end{array}$ & $\begin{array}{l}\text { Climate } \\
\text { change } \\
\text { Ecosystem } \\
\text { degradation }\end{array}$ & $\mathrm{EbA} / \mathrm{EbM}$ & $\begin{array}{l}\text { Green (e.g., green } \\
\text { space, Montado, } \\
\text { Circum- } \\
\text { Mediterranean } \\
\text { agricultural land) } \\
\text { Blue (e.g., coastal } \\
\text { environment, } \\
\text { islands) } \\
\text { Hybrid (e.g., } \\
\text { coastal 'cultural } \\
\text { ecosystem } \\
\text { services') }\end{array}$ \\
\hline
\end{tabular}


Table A1. Cont.

\begin{tabular}{|c|c|c|c|c|c|c|c|c|}
\hline & $\begin{array}{l}\text { Type of } \\
\text { Call/Funding } \\
\text { Scheme }\end{array}$ & $\begin{array}{l}\text { Funded } \\
\text { Projects/Duration/Scope/Web } \\
\text { Portal }\end{array}$ & Budget $(€)$ & $\begin{array}{l}\text { Lead Coun- } \\
\text { try/Partners } \\
\text { Countries/No. } \\
\text { of Partners }\end{array}$ & $\begin{array}{l}\text { Study } \\
\text { Area/Scale }\end{array}$ & $\begin{array}{l}\text { Challenged } \\
\text { Addressed }\end{array}$ & $\begin{array}{l}\text { NbS-Related } \\
\text { Concept }\end{array}$ & $\begin{array}{l}\text { Type of NbS De- } \\
\text { veloped/Tested }\end{array}$ \\
\hline $\begin{array}{l}\text { ENV.2013.6.2-5- } \\
\text { Urban biodiversity } \\
\text { and green } \\
\text { infrastructure }\end{array}$ & $\mathrm{CP}$ & $\begin{array}{l}\text { GREEN SURGE-Green } \\
\text { Infrastructure and urban biodiversity } \\
\text { for sustainable urban development } \\
\text { and the green economy (2013-2017): } \\
\text { identify, develop, and test ways of } \\
\text { connecting green spaces, biodiversity, } \\
\text { people, and the green economy. } \\
\text { https:/ / cordis.europa.eu/project/ } \\
\text { id/603567 (accessed on } 28 \text { September } \\
\text { 2021) } \\
\text { https: } \\
\text { //ign.ku.dk/english/green-surge } \\
\text { (accessed on } 30 \text { June 2021) }\end{array}$ & $7,189,726$ & $\begin{array}{l}\text { DK/FI, DE, NL, } \\
\text { SE, UK, HU, IT, } \\
\text { PO, PT, SI, } \\
\text { DK } 24 \text { partners } \\
\text { (11 countries) }\end{array}$ & Europe & $\begin{array}{l}\text { Land use } \\
\text { conflicts } \\
\text { Climate } \\
\text { change } \\
\text { Human health } \\
\text { and well-being } \\
\text { issues }\end{array}$ & GBI/BGI & $\begin{array}{l}\text { Green (e.g., city } \\
\text { parks, green walls, } \\
\text { rooftop gardens, } \\
\text { urban forests, } \\
\text { allotment gardens) } \\
\text { Blue (e.g., lakers, } \\
\text { rivers) }\end{array}$ \\
\hline
\end{tabular}


Table A1. Cont.

\begin{tabular}{|c|c|c|c|c|c|c|c|c|}
\hline & $\begin{array}{l}\text { Type of } \\
\text { Call/Funding } \\
\text { Scheme }\end{array}$ & $\begin{array}{l}\text { Funded } \\
\text { Projects/Duration/Scope/Web } \\
\text { Portal }\end{array}$ & Budget $(€)$ & $\begin{array}{l}\text { Lead Coun- } \\
\text { try/Partners } \\
\text { Countries/No. } \\
\text { of Partners }\end{array}$ & $\begin{array}{l}\text { Study } \\
\text { Area/Scale }\end{array}$ & $\begin{array}{l}\text { Challenged } \\
\text { Addressed }\end{array}$ & $\begin{array}{l}\text { NbS-Related } \\
\text { Concept }\end{array}$ & $\begin{array}{l}\text { Type of NbS De- } \\
\text { veloped/Tested }\end{array}$ \\
\hline $\begin{array}{l}\text { SC5-09-2014- } \\
\text { Consolidating the } \\
\text { European } \\
\text { Research Area on } \\
\text { biodiversity and } \\
\text { ecosystem services }\end{array}$ & $\begin{array}{l}\text { ERA-NET } \\
\text { Co-funded }\end{array}$ & $\begin{array}{l}\text { BiodivERsA3-Consolidating the } \\
\text { European research area on } \\
\text { biodiversity and ecosystem services } \\
\text { (78 projects) (2015-2020): provide } \\
\text { policymakers and other stakeholders } \\
\text { with adequate knowledge, tools, and } \\
\text { practical solutions to address } \\
\text { biodiversity and ecosystem } \\
\text { degradation. https:/ / cordis.europa. } \\
\text { eu/project/id/642420 (accessed on } \\
28 \text { September } \\
\text { 2021)http:/ / www.biodiversa.org } \\
\text { (accessed on 1 July 2021) } \\
\text { https: } \\
\text { //www.era-learn.eu/network- } \\
\text { information/networks/biodiversa3 } \\
\text { (accessed on 1 July 2021) }\end{array}$ & $38,974,333$ & $\begin{array}{l}\text { FR/AT, BE, BG, } \\
\text { EE, FR, NC, DE, } \\
\text { HU, LT, NL, NO, } \\
\text { PO, PT, RO, ES, } \\
\text { SE, CH, TR, UK, } \\
\text { SK, FI, IE, IL/37 } \\
\text { partners ( } 24 \\
\text { countries) }\end{array}$ & Europe & $\begin{array}{l}\text { Climate } \\
\text { change } \\
\text { Loss of } \\
\text { biodiversity } \\
\text { Degradation of } \\
\text { ecosystems }\end{array}$ & $\begin{array}{l}\mathrm{EbA} / \mathrm{EbM}, \\
\mathrm{BGI} / \mathrm{GBI}\end{array}$ & $\begin{array}{l}\text { Green (e.g., Beech } \\
\text { forests, grassland, } \\
\text { Congo Basin } \\
\text { forests, } \\
\text { heathlands) } \\
\text { Blue (e.g., Marine } \\
\text { Environments } \\
\text { Hybrid (e.g., } \\
\text { peatland; } \\
\text { terrestrial, } \\
\text { freshwater, and } \\
\text { marine systems } \\
\text { and its } \\
\text { interactions) }\end{array}$ \\
\hline
\end{tabular}


Table A1. Cont.

\begin{tabular}{|c|c|c|c|c|c|c|c|c|}
\hline & $\begin{array}{l}\text { Type of } \\
\text { Call/Funding } \\
\text { Scheme }\end{array}$ & $\begin{array}{l}\text { Funded } \\
\text { Projects/Duration/Scope/Web } \\
\text { Portal }\end{array}$ & Budget $(€)$ & $\begin{array}{l}\text { Lead Coun- } \\
\text { try/Partners } \\
\text { Countries/No. } \\
\text { of Partners }\end{array}$ & $\begin{array}{l}\text { Study } \\
\text { Area/Scale }\end{array}$ & $\begin{array}{l}\text { Challenged } \\
\text { Addressed }\end{array}$ & $\begin{array}{l}\text { NbS-Related } \\
\text { Concept }\end{array}$ & $\begin{array}{l}\text { Type of NbS De- } \\
\text { veloped/Tested }\end{array}$ \\
\hline
\end{tabular}


Table A1. Cont.

\begin{tabular}{|c|c|c|c|c|c|c|c|c|}
\hline & $\begin{array}{l}\text { Type of } \\
\text { Call/Funding } \\
\text { Scheme }\end{array}$ & $\begin{array}{l}\text { Funded } \\
\text { Projects/Duration/Scope/Web } \\
\text { Portal }\end{array}$ & Budget $(€)$ & $\begin{array}{l}\text { Lead Coun- } \\
\text { try/Partners } \\
\text { Countries/No. } \\
\text { of Partners }\end{array}$ & $\begin{array}{l}\text { Study } \\
\text { Area/Scale }\end{array}$ & $\begin{array}{l}\text { Challenged } \\
\text { Addressed }\end{array}$ & $\begin{array}{l}\text { NbS-Related } \\
\text { Concept }\end{array}$ & $\begin{array}{l}\text { Type of NbS De- } \\
\text { veloped/Tested }\end{array}$ \\
\hline
\end{tabular}


Table A1. Cont.

\begin{tabular}{|c|c|c|c|c|c|c|c|c|}
\hline & $\begin{array}{l}\text { Type of } \\
\text { Call/Funding } \\
\text { Scheme }\end{array}$ & $\begin{array}{l}\text { Funded } \\
\text { Projects/Duration/Scope/Web } \\
\text { Portal }\end{array}$ & Budget $(€)$ & $\begin{array}{l}\text { Lead Coun- } \\
\text { try/Partners } \\
\text { Countries/No. } \\
\text { of Partners }\end{array}$ & $\begin{array}{l}\text { Study } \\
\text { Area/Scale }\end{array}$ & $\begin{array}{l}\text { Challenged } \\
\text { Addressed }\end{array}$ & $\begin{array}{l}\text { NbS-Related } \\
\text { Concept }\end{array}$ & $\begin{array}{l}\text { Type of NbS De- } \\
\text { veloped/Tested }\end{array}$ \\
\hline $\begin{array}{l}\text { SC5-09-2016- } \\
\text { Operationalizing } \\
\text { insurance value of } \\
\text { ecosystems }\end{array}$ & RIA & $\begin{array}{l}\text { NAIAD—Nature insurance value: assessment } \\
\text { and demonstration (2016-2020): operationalize } \\
\text { the insurance value of ecosystems to reduce the } \\
\text { human and economic cost of risks associated } \\
\text { with floods and drought by developing and } \\
\text { testing the concepts, tools, applications, and } \\
\text { business models for its mainstreaming. } \\
\text { https://cordis.europa.eu/project/id/730497 } \\
\text { (accessed on } 2 \text { July 2021) } \\
\text { www.naiad2020.eu (accessed on } 2 \text { July 2021) }\end{array}$ & $5,081,176$ & $\begin{array}{l}\text { ES/FR, UK, ES, } \\
\text { PO, SI, IT, DE, } \\
\text { SE, RO, DK, } \\
\text { NL/23 partners } \\
\text { (10 countries) }\end{array}$ & Europe & Flood, drought & $\begin{array}{l}\text { GBI/BGI, GI, } \\
\text { EE }\end{array}$ & $\begin{array}{l}\text { Green (e.g., permeable } \\
\text { pavements, bioswales, } \\
\text { green roofs, open } \\
\text { retention basins, rain } \\
\text { gardens, Façade } \\
\text { gardens, green strips } \\
\text { and swales). } \\
\text { Blue (e.g., Retention } \\
\text { ponds) } \\
\text { Hybrid (e.g., expansion } \\
\text { of central green } \\
\text { Space, separated sewer } \\
\text { for water } \\
\text { collection and } \\
\text { distribution) }\end{array}$ \\
\hline
\end{tabular}


Table A1. Cont.

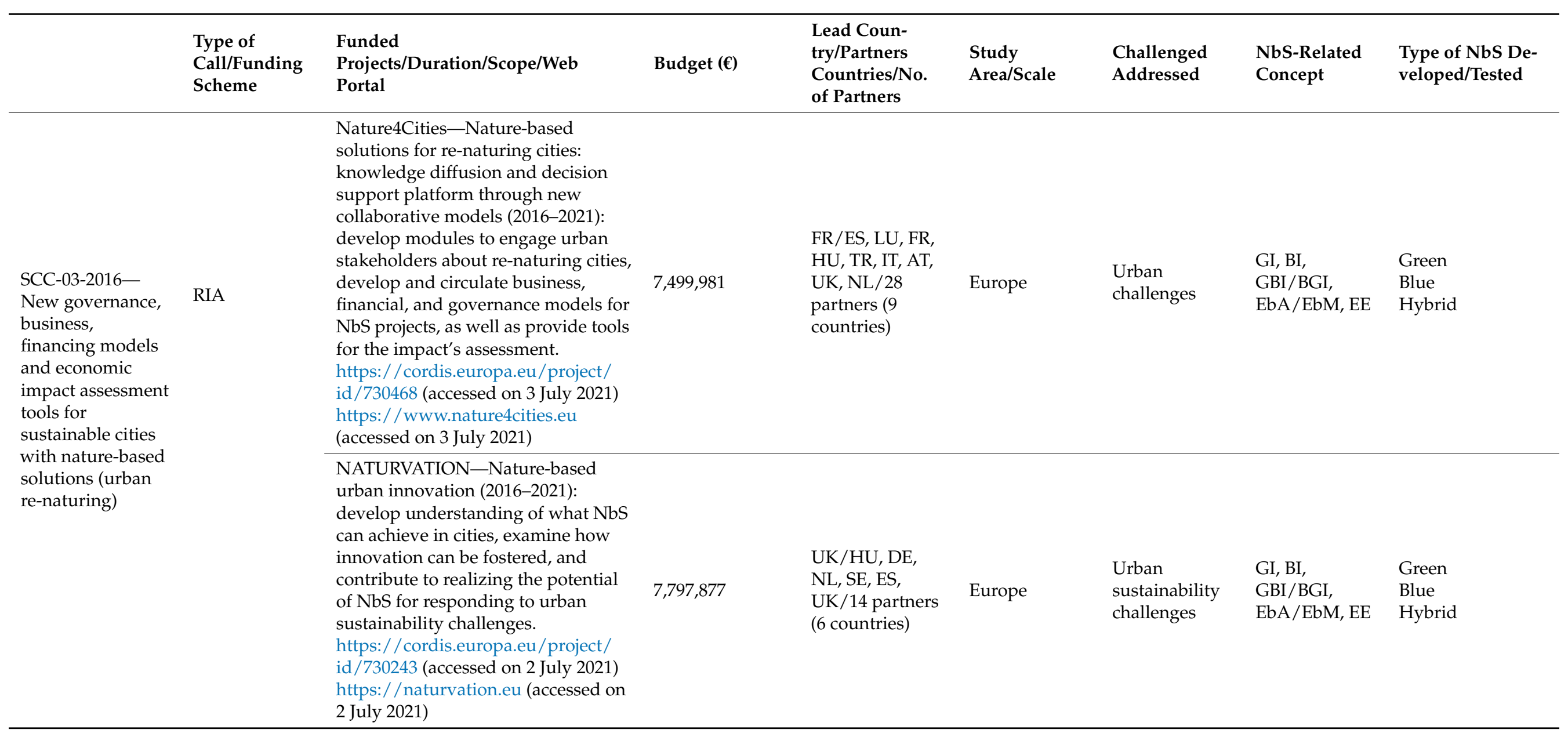


Table A1. Cont.

\begin{tabular}{|c|c|c|c|c|c|c|c|c|}
\hline & $\begin{array}{l}\text { Type of } \\
\text { Call/Funding } \\
\text { Scheme }\end{array}$ & $\begin{array}{l}\text { Funded } \\
\text { Projects/Duration/Scope/Web } \\
\text { Portal }\end{array}$ & Budget $(€)$ & $\begin{array}{l}\text { Lead Coun- } \\
\text { try/Partners } \\
\text { Countries/No. } \\
\text { of Partners }\end{array}$ & $\begin{array}{l}\text { Study } \\
\text { Area/Scale }\end{array}$ & $\begin{array}{l}\text { Challenged } \\
\text { Addressed }\end{array}$ & $\begin{array}{l}\text { NbS-Related } \\
\text { Concept }\end{array}$ & $\begin{array}{l}\text { Type of NbS De- } \\
\text { veloped/Tested }\end{array}$ \\
\hline $\begin{array}{l}\text { SC5-23-2016- } \\
\text { 2017-Support to } \\
\text { confirmed } \\
\text { Presidency events } \\
\text { (conferences)- } \\
\text { Malta, United } \\
\text { Kingdom, Estonia }\end{array}$ & CSA & $\begin{array}{l}\text { NBS2017-NbS: from innovation to } \\
\text { common-use (2017-2018): strengthen } \\
\text { synergy among various recent } \\
\text { initiatives and programs launched by } \\
\text { the EC and the Member States and } \\
\text { develop recommendations for future } \\
\text { practical solutions and actions. } \\
\text { https: / cordis.europa.eu/project/ } \\
\text { id/769003 (accessed on } 2 \text { July 2021) } \\
\text { https: / / www.nbs2017.eu (accessed } \\
\text { on } 2 \text { July 2021) }\end{array}$ & 274,517 & $\begin{array}{l}\mathrm{EE} / \mathrm{EE} / 2 \\
\text { partners }(1 \\
\text { country })\end{array}$ & $\begin{array}{l}\text { National and } \\
\text { EU level }\end{array}$ & $\begin{array}{l}\text { Natural capital } \\
\text { Resource- } \\
\text { efficiency and } \\
\text { innovation } \\
\text { Health and } \\
\text { well-being } \\
\text { Earth's natural } \\
\text { limit }\end{array}$ & $\begin{array}{l}\text { GI, BI, } \\
\text { GBI/BGI, } \\
\text { EbA/EbM, EE }\end{array}$ & NA \\
\hline
\end{tabular}


Table A1. Cont.

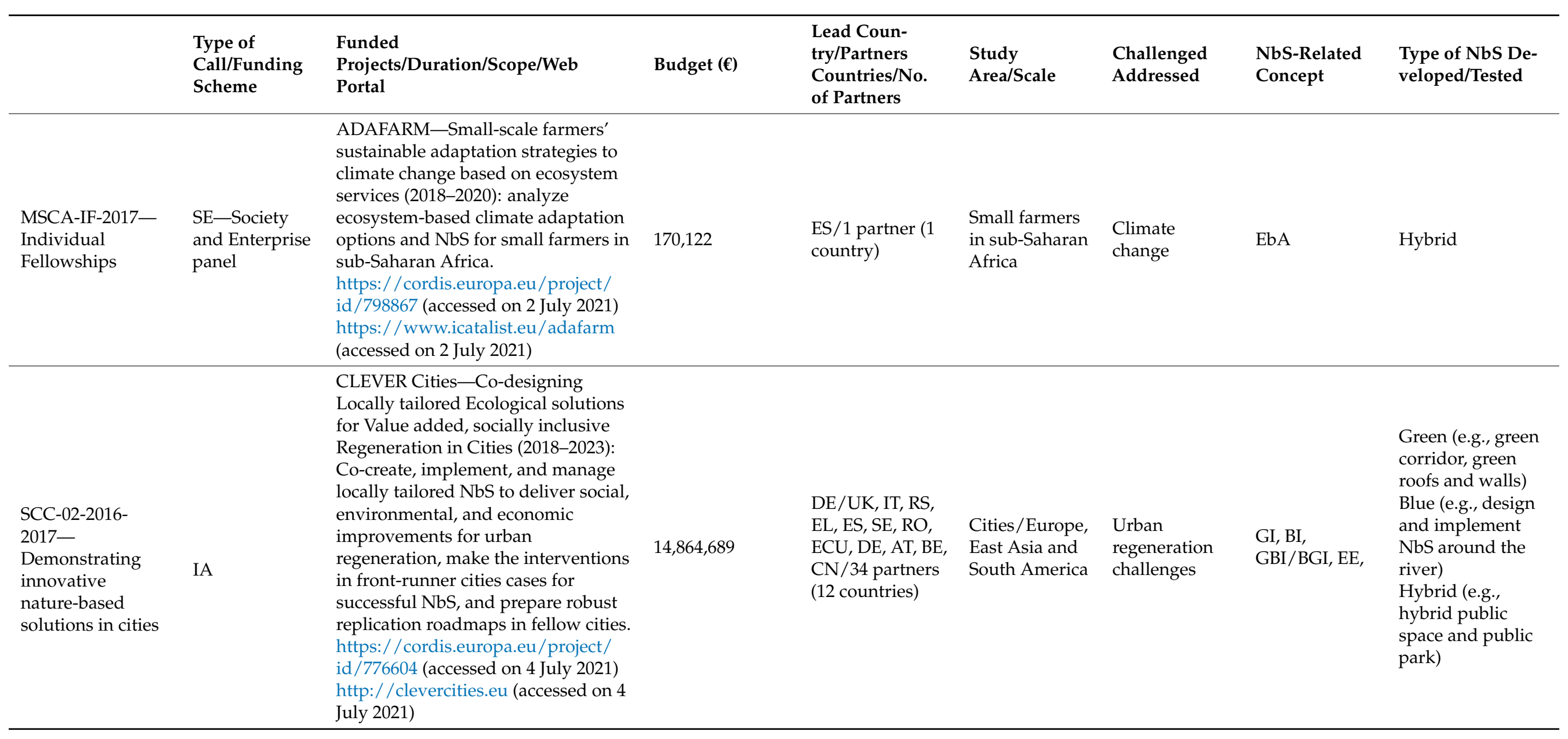


Table A1. Cont.

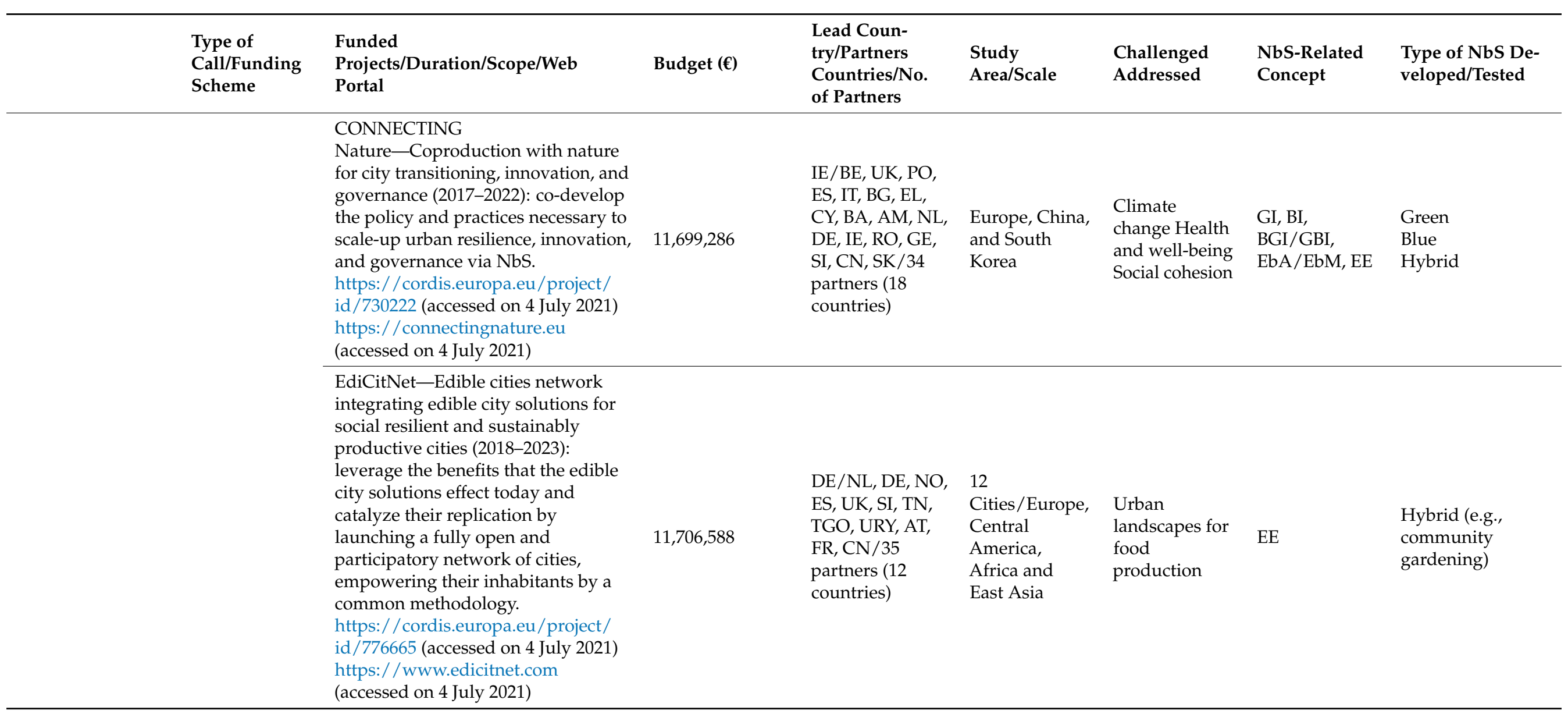


Table A1. Cont.

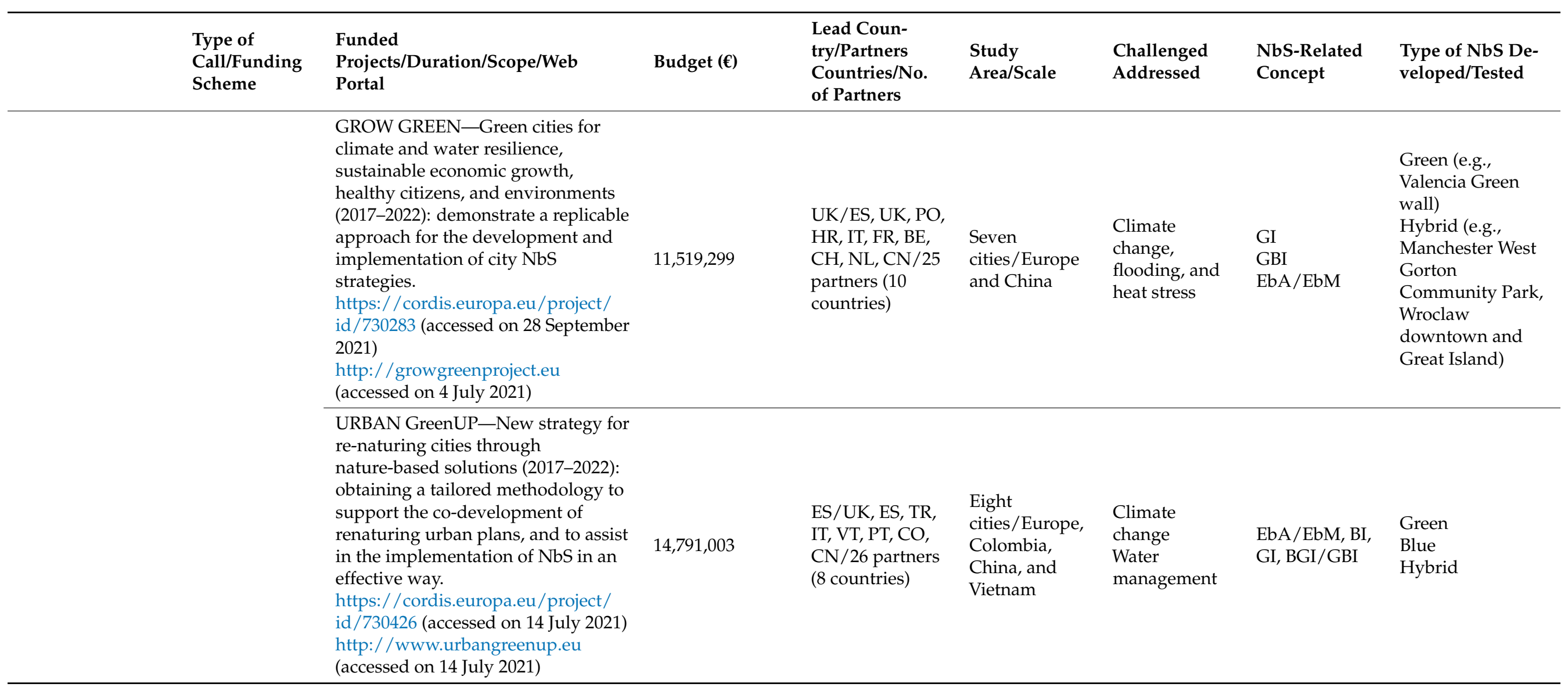


Table A1. Cont.

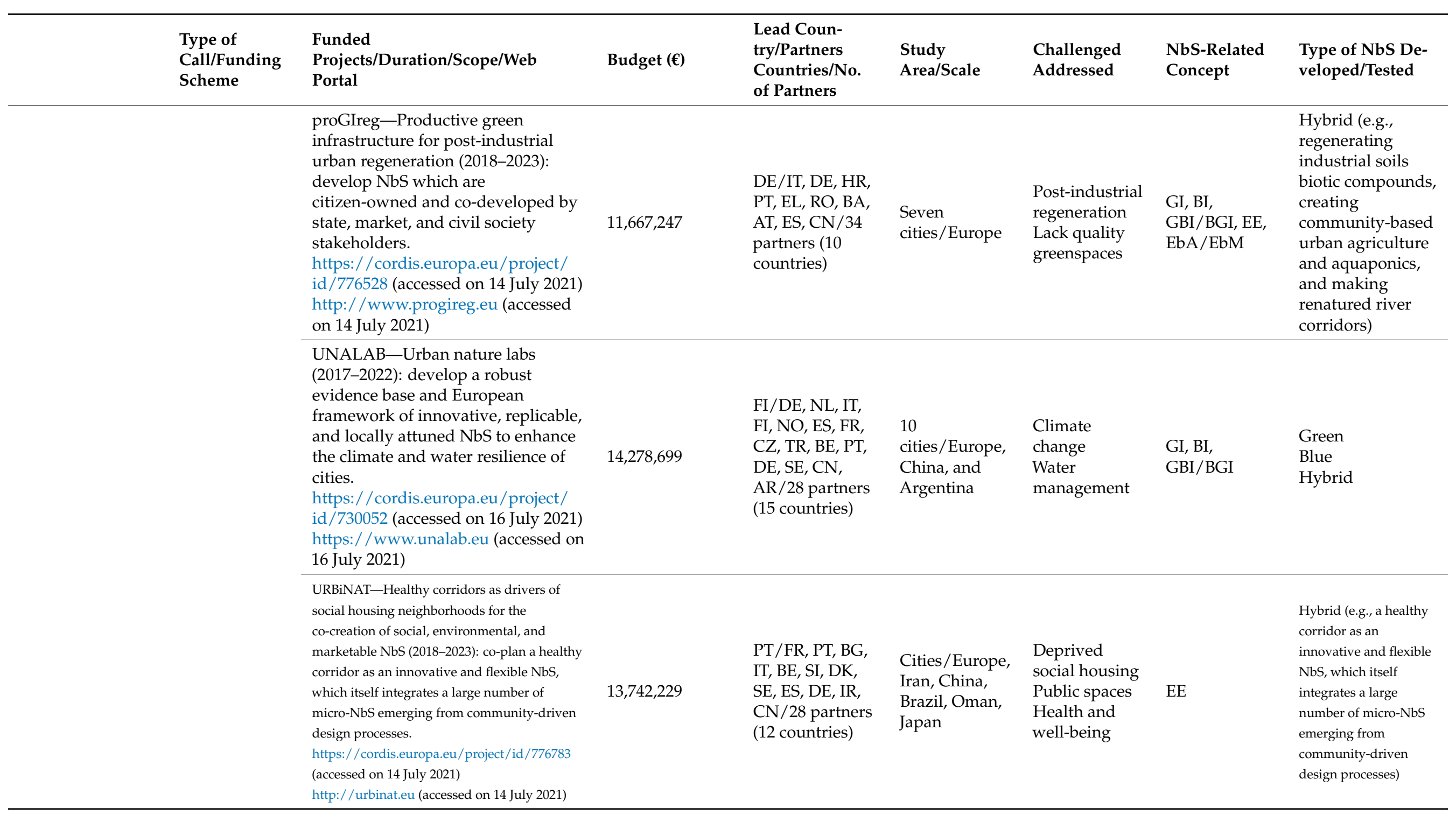


Table A1. Cont.

\begin{tabular}{|c|c|c|c|c|c|c|c|c|}
\hline & $\begin{array}{l}\text { Type of } \\
\text { Call/Funding } \\
\text { Scheme }\end{array}$ & $\begin{array}{l}\text { Funded } \\
\text { Projects/Duration/Scope/Web } \\
\text { Portal }\end{array}$ & Budget $(€)$ & $\begin{array}{l}\text { Lead Coun- } \\
\text { try/Partners } \\
\text { Countries/No. } \\
\text { of Partners }\end{array}$ & $\begin{array}{l}\text { Study } \\
\text { Area/Scale }\end{array}$ & $\begin{array}{l}\text { Challenged } \\
\text { Addressed }\end{array}$ & $\begin{array}{l}\text { NbS-Related } \\
\text { Concept }\end{array}$ & $\begin{array}{l}\text { Type of NbS De- } \\
\text { veloped/Tested }\end{array}$ \\
\hline
\end{tabular}


Table A1. Cont.

\begin{tabular}{|c|c|c|c|c|c|c|c|c|}
\hline & $\begin{array}{l}\text { Type of } \\
\text { Call/Funding } \\
\text { Scheme }\end{array}$ & $\begin{array}{l}\text { Funded } \\
\text { Projects/Duration/Scope/Web } \\
\text { Portal }\end{array}$ & Budget $(€)$ & $\begin{array}{l}\text { Lead Coun- } \\
\text { try/Partners } \\
\text { Countries/No. } \\
\text { of Partners }\end{array}$ & $\begin{array}{l}\text { Study } \\
\text { Area/Scale }\end{array}$ & $\begin{array}{l}\text { Challenged } \\
\text { Addressed }\end{array}$ & $\begin{array}{l}\text { NbS-Related } \\
\text { Concept }\end{array}$ & $\begin{array}{l}\text { Type of } \mathrm{NbS} \mathrm{De} \\
\text { veloped/Tested }\end{array}$ \\
\hline
\end{tabular}


Table A1. Cont.

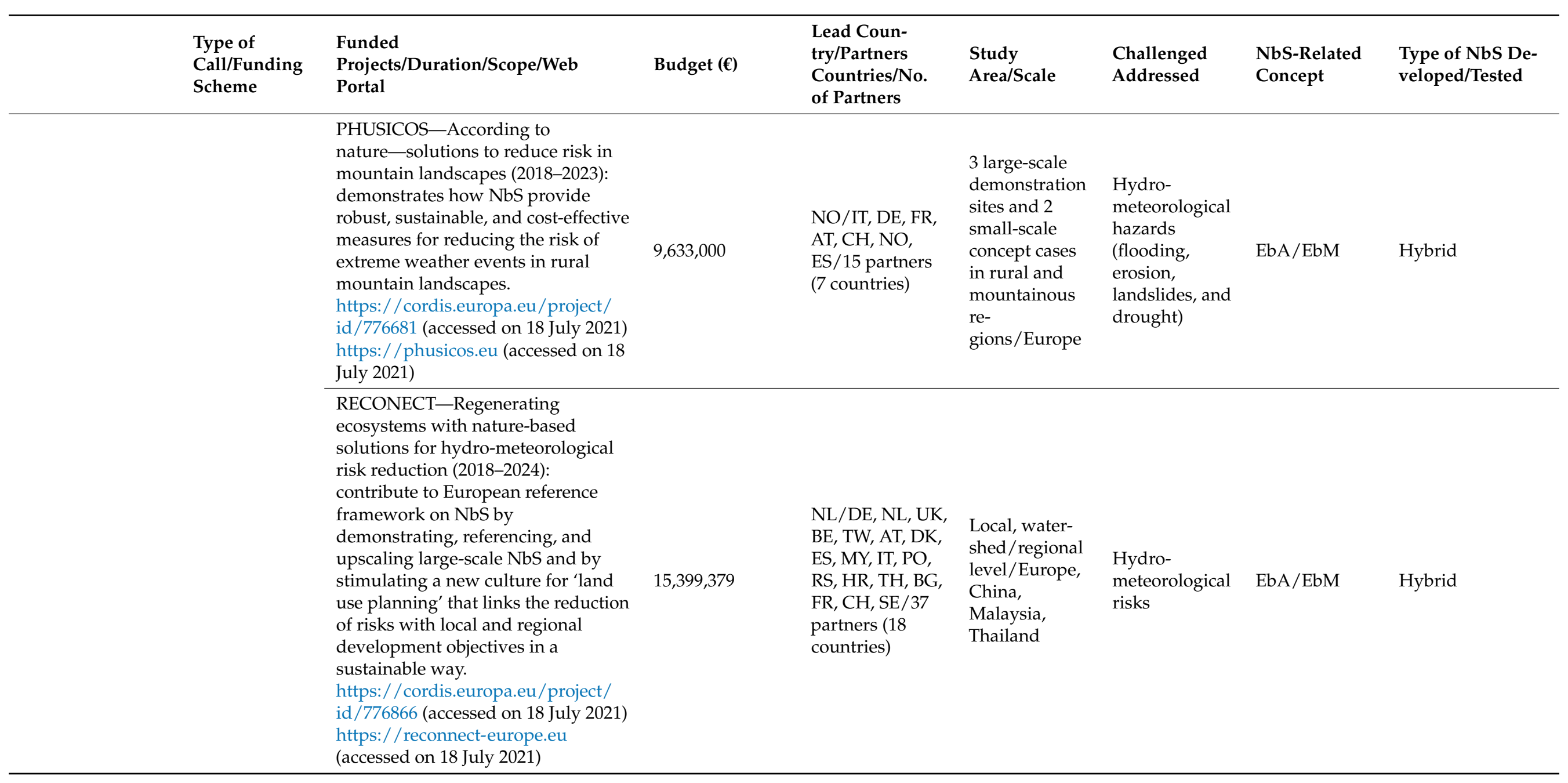


Table A1. Cont.

\begin{tabular}{|c|c|c|c|c|c|c|c|c|}
\hline & $\begin{array}{l}\text { Type of } \\
\text { Call/Funding } \\
\text { Scheme }\end{array}$ & $\begin{array}{l}\text { Funded } \\
\text { Projects/Duration/Scope/Web } \\
\text { Portal }\end{array}$ & Budget $(€)$ & $\begin{array}{l}\text { Lead Coun- } \\
\text { try/Partners } \\
\text { Countries/No. } \\
\text { of Partners }\end{array}$ & $\begin{array}{l}\text { Study } \\
\text { Area/Scale }\end{array}$ & $\begin{array}{l}\text { Challenged } \\
\text { Addressed }\end{array}$ & $\begin{array}{l}\text { NbS-Related } \\
\text { Concept }\end{array}$ & $\begin{array}{l}\text { Type of } \mathrm{NbS} \mathrm{De} \\
\text { veloped/Tested }\end{array}$ \\
\hline $\begin{array}{l}\text { SwafS-15-2018- } \\
\text { 2019-Exploring } \\
\text { and supporting } \\
\text { citizen science }\end{array}$ & RIA & $\begin{array}{l}\text { MICS-Developing metrics and } \\
\text { instruments to evaluate citizen } \\
\text { science impacts on the environment } \\
\text { and society (2019-2021): support } \\
\text { NbS research by developing } \\
\text { strategies and tools to evaluate } \\
\text { impacts on science and society } \\
\text { resulting from the integration of } \\
\text { citizen science. } \\
\text { https: / / cordis.europa.eu/project/ } \\
\text { id/824711 (accessed on 18 July 2021) } \\
\text { https:/ / mics.tools (accessed on } 18 \\
\text { July 2021) }\end{array}$ & $1,944,428$ & $\begin{array}{l}\mathrm{UK} / \mathrm{NL}, \mathrm{IT}, \mathrm{HU}, \\
\mathrm{UK}, \mathrm{RO} / 6 \\
\text { partners }(5 \\
\text { countries) }\end{array}$ & West-East EU & $\begin{array}{l}\text { Societal } \\
\text { challenges in } \\
\text { general }\end{array}$ & $\begin{array}{l}\mathrm{EE}, \\
\mathrm{BGI} / \mathrm{GBI}, \mathrm{EbA} / \mathrm{EbM}\end{array}$ & Hybrid \\
\hline $\begin{array}{l}\text { SC5-13-2018- } \\
\text { Strengthening } \\
\text { EU-China } \\
\text { cooperation on } \\
\text { sustainable } \\
\text { urbanization: } \\
\text { nature-based } \\
\text { solutions for } \\
\text { restoration and } \\
\text { rehabilitation of } \\
\text { urban ecosystems }\end{array}$ & vspace-56ptRIA & $\begin{array}{l}\text { CLEARING HOUSE-Collaborative } \\
\text { learning in research, } \\
\text { information-sharing, and governance } \\
\text { on how urban tree-based solutions } \\
\text { support Sino-European urban } \\
\text { futures (2019-2023): investigate the } \\
\text { role of urban forests as NbS, which } \\
\text { refers to all measures a city can take } \\
\text { to address urban sustainable } \\
\text { development challenges by planting } \\
\text { and managing trees. } \\
\text { https: / cordis.europa.eu/project/ } \\
\text { id/821242 (accessed on 19 July 2021) } \\
\text { https://clearinghouseproject.eu } \\
\text { (accessed on 18 July 2021) }\end{array}$ & $7,687,864$ & $\begin{array}{l}\text { FI/CN, PO, DE, } \\
\text { ES, FR, IT, FI, AT, } \\
\text { HR, BE, HK, } \\
\text { CH/ } 26 \text { partners } \\
\text { (12 countries) }\end{array}$ & $\begin{array}{l}\text { Cities/Europe } \\
\text { and China }\end{array}$ & $\begin{array}{l}\text { Lack of } \\
\text { adequate } \\
\text { green } \\
\text { infrastructure }\end{array}$ & GI & $\begin{array}{l}\text { Green } \\
\text { Hybrid }\end{array}$ \\
\hline
\end{tabular}


Table A1. Cont.

\begin{tabular}{|c|c|c|c|c|c|c|c|c|}
\hline & $\begin{array}{l}\text { Type of } \\
\text { Call/Funding } \\
\text { Scheme }\end{array}$ & $\begin{array}{l}\text { Funded } \\
\text { Projects/Duration/Scope/Web } \\
\text { Portal }\end{array}$ & Budget $(€)$ & $\begin{array}{l}\text { Lead Coun- } \\
\text { try/Partners } \\
\text { Countries/No. } \\
\text { of Partners }\end{array}$ & $\begin{array}{l}\text { Study } \\
\text { Area/Scale }\end{array}$ & $\begin{array}{l}\text { Challenged } \\
\text { Addressed }\end{array}$ & $\begin{array}{l}\text { NbS-Related } \\
\text { Concept }\end{array}$ & $\begin{array}{l}\text { Type of NbS De- } \\
\text { veloped/Tested }\end{array}$ \\
\hline
\end{tabular}


Table A1. Cont.

\begin{tabular}{|c|c|c|c|c|c|c|c|c|}
\hline \multirow{2}{*}{$\begin{array}{l}\text { SC5-13-2019- } \\
\text { Strengthening } \\
\text { EU-CELAC } \\
\text { cooperation on } \\
\text { sustainable } \\
\text { urbanization: } \\
\text { nature-based } \\
\text { solutions for } \\
\text { restoration and } \\
\text { rehabilitation of } \\
\text { urban ecosystems }\end{array}$} & \multirow[t]{2}{*}{ RIA } & $\begin{array}{l}\text { CONEXUS-CO-producing } \\
\text { Nature-based solutions and restored } \\
\text { Ecosystems: transdisciplinary neXus } \\
\text { for Urban Sustainability (2020-2024): } \\
\text { Co-create context-appropriate NbS } \\
\text { for ecosystems restoration and } \\
\text { sustainable urbanization in CELAC } \\
\text { and EU cities, using a place-based } \\
\text { approach. } \\
\text { https:/ / cordis.europa.eu/project/ } \\
\text { id/867564 (accessed on } 19 \text { July 2021) } \\
\text { https://www.conexusnbs.com } \\
\text { (accessed on } 19 \text { July 2021) }\end{array}$ & $6,203,619$ & $\begin{array}{l}\text { UK/SE, NL, DE, } \\
\mathrm{CO}, \mathrm{IT}, \mathrm{PT}, \mathrm{CL}, \\
\mathrm{BR}, \mathrm{AR}, \mathrm{ES}, \mathrm{RO}, \\
\text { PE/30 partners } \\
\text { (13 countries) }\end{array}$ & $\begin{array}{l}\text { São Paulo, } \\
\text { Bogotá, } \\
\text { Santiago, } \\
\text { Buenos Aires, } \\
\text { Lisbon, } \\
\text { Barcelona and } \\
\text { Turin }\end{array}$ & $\begin{array}{l}\text { Landscape } \\
\text { fragmentation, } \\
\text { urban sprawl, } \\
\text { lacking green } \\
\text { area }\end{array}$ & $\mathrm{EbA} / \mathrm{EbM}$ & Hybrid \\
\hline & & $\begin{array}{l}\text { INTERLACE-International } \\
\text { cooperation to restore and connect } \\
\text { urban environments in Latin } \\
\text { America and Europe (2020-2024): } \\
\text { Connect cities from Europe and Latin } \\
\text { American and equip them to restore } \\
\text { and rehabilitate (peri)urban } \\
\text { ecosystems. } \\
\text { https: / / cordis.europa.eu/project/ } \\
\text { id/869324 (accessed on 25 June 2021) } \\
\text { https:/ /interlace-project.eu } \\
\text { (accessed on 25 June 2021) }\end{array}$ & $5,476,165$ & $\begin{array}{l}\text { DE/ECU, ES, } \\
\mathrm{CR}, \mathrm{PO}, \mathrm{BE}, \mathrm{NO}, \\
\mathrm{FR}, \mathrm{DE}, \mathrm{CO}, \mathrm{NL}, \\
\mathrm{MX} / 21 \text { partners } \\
\text { (11 countries) }\end{array}$ & $\begin{array}{l}\text { Granollers } \\
\text { (Spain) } \\
\text { Envigado } \\
\text { (Colombia) } \\
\text { Portoviejo } \\
\text { (Ecuador) } \\
\text { Chemnitz } \\
\text { (Germany) } \\
\text { Krakow } \\
\text { (Poland) } \\
\text { CBIMA (Costa } \\
\text { Rica) }\end{array}$ & $\begin{array}{l}\text { Urban } \\
\text { ecosystem } \\
\text { degradation }\end{array}$ & $\mathrm{EbA} / \mathrm{EbM}$ & $\begin{array}{l}\text { Hybrid (e.g., } \\
\text { restore and } \\
\text { rehabilitate } \\
\text { (peri)urban } \\
\text { ecosystems. }\end{array}$ \\
\hline $\begin{array}{l}\text { SC5-14-2019- } \\
\text { Visionary and } \\
\text { integrated } \\
\text { solutions to } \\
\text { improve } \\
\text { well-being and } \\
\text { health in cities }\end{array}$ & IA & $\begin{array}{l}\text { VARCITIES-Visionary nature-based } \\
\text { actions for health, wellbeing \& } \\
\text { resilience in cities (2020-2025): } \\
\text { Create a vision for future cities with } \\
\text { the citizen and human community at } \\
\text { the center, implement innovative } \\
\text { ideas and add value by creating } \\
\text { sustainable models for improving the } \\
\text { health and well-being of citizens } \\
\text { https: / / cordis.europa.eu/project/ } \\
\text { id / } 869505 \text { (accessed on } 15 \text { July 2021) } \\
\text { https:/ / www.varcities.eu (accessed } \\
\text { on } 15 \text { July 2021) }\end{array}$ & $11,129,570$ & $\begin{array}{l}\text { EL/EL, IT, MT, } \\
\text { SI, BE, IE, SE, } \\
\text { NL, NO/ } 25 \\
\text { partners ( } 9 \\
\text { countries) }\end{array}$ & $\begin{array}{l}\text { Eight } \\
\text { cities/Europe }\end{array}$ & $\begin{array}{l}\text { Urbanization } \\
\text { and air } \\
\text { pollution } \\
\text { Urban } \\
\text { exacerbation of } \\
\text { heat islands }\end{array}$ & $\begin{array}{l}\text { GBI/BGI, EE, } \\
\mathrm{EbA} / \mathrm{EbM}\end{array}$ & $\begin{array}{l}\text { Green } \\
\text { Blue } \\
\text { Hybrid }\end{array}$ \\
\hline
\end{tabular}


Table A1. Cont.

IN-HABIT-INclusive Health And

wellBeing In small and medium size

ciTies (2020-2025): design integrative

actions that will be shaped according

to the needs of local vulnerable

groups in four cities, based on

culture, food, art and bonds with

nature and animals combined with

technological and digital means.

https:/ / cordis.europa.eu/project/

id / 869227 (accessed on 16 June 2021)

https: / /www.inhabit-h2020.eu

(accessed on 16 June 2021)

EuPOLIS-Integrated NBS-based Urban

Planning Methodology for Enhancing the

Health and Well-being of Citizens:

The EuPOLIS Approach (2020-2024): deploy natural systems to enhance public health and

well-being and create resilient urban

ecosystems, and regenerate and rehabilitate

urban ecosystems to create inclusive and

accessible urban spaces.

https://cordis.europa.eu/project/id/869448

(accessed on 19 June 2021)

https: / / eupolis-project.eu (accessed on 19

June 2021)

GOGREEN ROUTES—GO GREEN: Resilien

Optimal Urban natural, Technological and

Environmental Solutions (2020-2024): position

European cities as world ambassadors of urban

sustainability, shifts the focus of $\mathrm{NbS}$ towards

the co-benefits to multidimensional

health-termed 360-Health.

https:// cordis.europa.eu/project/id/86976

(accessed on 19 July 2021)

https:/ / gogreenroutes.eu (accessed on 19 July

2021)

(a)
ES/ES, LV, IT,

$\mathrm{SK}, \mathrm{UK}, \mathrm{DE}, \mathrm{BE}$

$\mathrm{CO} / 21$ partners

(8 countries)
Five

$11,577,919$

AT, EL, UK, HU,

$\mathrm{DE}, \mathrm{CH}, \mathrm{CO}, \mathrm{IT}$

CY, BA, CN $/ 28$

partners (14

countries)
Low

environmental

quality and

low

biodiversity in

public spaces

Water-stressed

resources and

undervalued

use of space
Hybrid (e.g.,

sustainable

mobility and

creative square in

Cordoba)

$\begin{array}{ll}\text { EE, GBI/BGI, } & \text { Green } \\ \text { EbA/EbM } & \text { Blue } \\ & \text { Hybrid }\end{array}$

Hybrid
IE/IE, DE, UK,

NO, EE, IT, FI,

$\mathrm{BE}, \mathrm{ES}, \mathrm{FR}, \mathrm{CN}$ Cities/Europe

ES, DK, Mexico,

Georgia
Hybrid (route

connecting the

lakes of the city's

wetland complex

in Burgas, urban garden in Tallinn) health and

well-being
GBI/BGI, EE 
Table A1. Cont.

Green CURIOCITY-Green cure in

overheated city spaces: An

investigation of childhood

heat-related health impacts and

protective effects of urban natural

environments (2020-2022): improve

MSCA-IF-2019- MSCA-IF-EF- knowledge about how heat exposure

Individual RI-RI- during pregnancy impacts birth

Fellowships

Reintegration

panel

outcome and how long-term

exposure could affect children's

neurodevelopment and explore the

possibilities to mitigate or prevent

the negative effects of heat in the

context of $\mathrm{NbS}$.

https: / / cordis.europa.eu/project/

$\mathrm{id} / 891538$ (accessed on 19 July 2021)

\section{METABUILDING-Meta-clustering}

for cross-sectoral and cross-border

innovation ecosystem building for

the European construction, additive

manufacturing and $\mathrm{NbS}$ industrial

INNOSUP-01-

2018-2020-

Cluster facilitated

projects for new

industrial value

chains sectors' SMEs (2020-2023): joining

efforts with ICT, additive

manufacturing, $\mathrm{NbS}$, and the

recycling industry to underpin and

fuel the emergence of new

cross-sectoral, cross-border industrial

value chains.

https://cordis.europa.eu/project/

id/873964 (accessed on 18 July 2021)

https:/ / www.metabuilding.com

(accessed on 18 July 2021)
Overheating of

cities

172,932 ES/1 partner (1 Europe Children's GI Green

Green

health and

development

$\begin{array}{lll}\text { ES/1 partner (1 } & \text { Europe } & \begin{array}{l}\text { Children's } \\ \text { health and } \\ \text { developmen }\end{array}\end{array}$

(2)

(n)

(5,

5,

$5,126,625$

FR/BE, AT, ES,
PT, FR, IT, HU,
UK, DE/15

\section{More than 140 Lack of}

cross-border between

SME-led construction

partners (9 innovation and other

countries) ideas/projects/ industry

Europe sectors. 
Table A1. Cont.

\section{SC5-23-2019-}

Multi-stakeholder

dialogue platform

to promote

nature-based

solutions to

societal challenges:

follow-up project

\section{LC-CLA-06-}

2019-Inter-

relations between

climate change,

biodiversity, and

ecosystem services
NetworkNature-Advancing

nature-based solutions together

(2020-2023): establish a European

and global platform allowing all

interested stakeholders to access and

CSA

contribute cutting-edge, innovative

knowledge and expertise on $\mathrm{NbS}$.

https: / / cordis.europa.eu/project/

$\mathrm{id} / 887396$ (accessed on 28 June

2021)https: / networknature eu

(accessed on 26 June 2021)

FutureMARES-Climate Change and

future marine ecosystem services

and biodiversity (2020-2024):

investigate $\mathrm{NbS}$ for climate change

adaptation and mitigation, including

the restoration of habitat-forming

species that can buffer coastal

habitats from climate change effects

and improve seawater quality.

https:/ / cordis.europa.eu/project/

$\mathrm{id} / 869300$ (accessed on 26 June 2021)

https://www.futuremares.eu

(accessed on 26 June 2021)

\section{MaCoBioS-Marine coastal}

ecosystems biodiversity and services

in a changing world (2020-2024)

develop models on interactions

between climate change, biodiversity,

and functions and services of marine

coastal ecosystems, establish a

framework to assess vulnerabilities

and evaluate the effectiveness of $\mathrm{NbS}$.

https: / / cordis.europa.eu/ project/

$\mathrm{id} / 869710$ (accessed on 28 September

2021)

https: / / macobios.eu (accessed on 27

June 2021)

$\begin{array}{lllll}\mathrm{DE} / \mathrm{BE}, \mathrm{NL}, \mathrm{FR}, & & \text { GI, BI, } & \text { Green } \\ \mathrm{CH}, \mathrm{DE} / 6 & \text { Europe and } & \begin{array}{l}\text { Societal } \\ \text { challenges }\end{array} & \text { GBI/BGI, } & \text { Blue } \\ \text { partners }(6 & \text { Globe } & \text { EbA/EbM, EE } & \text { Hybrid } \\ \text { countries) } & & & \end{array}$

countries) Globe challenges EbA/EbM, EE Hybrid

\begin{tabular}{|c|c|c|c|c|c|}
\hline $8,555,905$ & $\begin{array}{l}\text { DE/DK, EL, ES, } \\
\text { CL, UK, PT, IT, } \\
\text { BZ, NL, DE, IL, } \\
\text { FR, NO, SE, } \\
\text { FI/33 partners } \\
\text { (15 countries) }\end{array}$ & Global & $\begin{array}{l}\text { Climate } \\
\text { change } \\
\text { Biodiversity } \\
\text { loss }\end{array}$ & $\mathrm{EbA} / \mathrm{EbM}$ & $\begin{array}{l}\text { Hybrid (e.g., } \\
\text { restoration of } \\
\text { costal } \\
\text { habitat-forming } \\
\text { species) }\end{array}$ \\
\hline
\end{tabular}

$\mathrm{DE} / \mathrm{DK}, \mathrm{EL}, \mathrm{ES}$,

CL, UK, PT, IT,

(15 countries)

species)

\begin{tabular}{|c|c|c|c|c|c|}
\hline $6,980,658$ & $\begin{array}{l}\text { UK/FR, PT, IE, } \\
\text { NL, ES, IT, DE, } \\
\text { SE, UK, JM, } \\
\text { NO/17 partners } \\
\text { (11 countries) }\end{array}$ & $\begin{array}{l}\text { Europe and } \\
\text { Jamaica }\end{array}$ & $\begin{array}{l}\text { Climate } \\
\text { chance, marine } \\
\text { coastal } \\
\text { ecosystems } \\
\text { degradation, } \\
\text { biodiversity } \\
\text { loss }\end{array}$ & $\mathrm{EbA} / \mathrm{EbM}$ & NA \\
\hline
\end{tabular}


Table A1. Cont.

DRYvER-Securing biodiversity,

functional integrity, and ecosystem

services in drying river networks

(2020-2024): collect, analyze, and

model data, create a novel global

meta-system approach, develop

strategies to mitigate climate change

effects on drying river networks, and

aid their adaptation mechanisms,

defining new tools and guidelines.

https: / / cordis.europa.eu/project/

$\mathrm{id} / 869226$ (accessed on 27 June 2021)

https://www.dryver.eu (accessed on

27 June 2021)

PONDERFUL-Pond ecosystems for

resilient future landscapes in a

changing climate (2020-2024):

investigate how ponds can be used

as $\mathrm{NbS}$ for climate change, evaluate

the interaction and feedback between

biodiversity, ecosystem services, and

climate in pondscapes, develop

future scenarios for pondscapes in

the EU, Latin American, and

Caribbean States (CELAC), where it

will conduct tests.

https: / / cordis.europa.eu/project/

id/869296 (accessed on 28 September 2021)

https:/ / ponderful.eu (accessed on 27

June 2021)
FR/DE, AT, NL,

ES, FI, HU, CZ,

Europe, South Climate

HR, FR, UK, SI,

$\mathrm{BR}, \mathrm{BO}, \mathrm{EC}$,

(15 countries)
America, and

change, drying $\mathrm{EbA} / \mathrm{EbM}$

China rivers

NA
$6,993,407$

ES/DE, BE, $\mathrm{CH}$

ES, UK, PT, DK,

SE, FR, URY/18

partners (10

EU, Latin

partners (10

\section{American and}

Caribbean

Climate

change

States
$\mathrm{EbA} / \mathrm{EbM}$ 
Table A1. Cont.

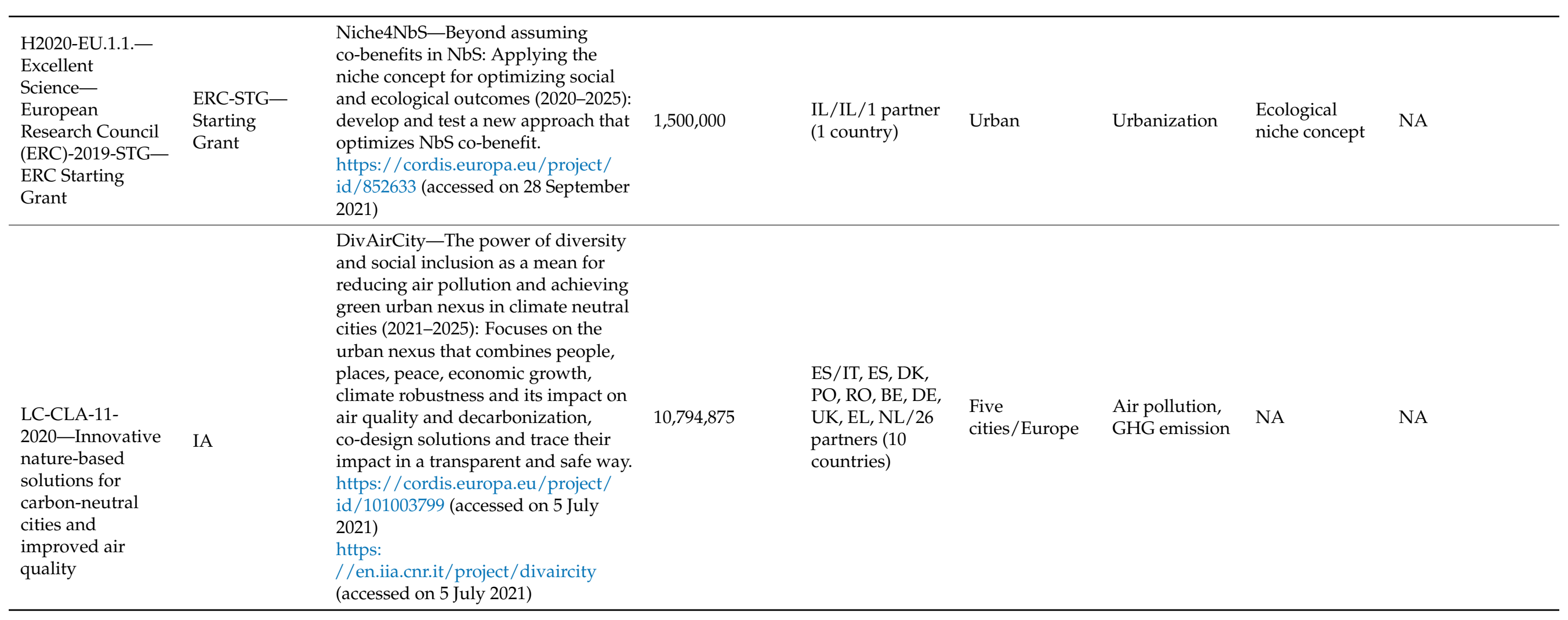


Table A1. Cont.

Upsurge-City-centered approach to

catalyze nature-based solutions

through the EU Regenerative Urban

Lighthouse for pollution alleviation

and regenerative development

(2021-2025): Present the European

Regenerative Urban Lighthouse,

enable cities to unlock their

regenerative potential, and provide

them with knowledge and guidance

in regenerative transition.

https: / / cordis.europa.eu/project/

id/101003818 (accessed on 28

September 2021)

https: / /www.katowice.eu/Strony /

UPSURGE.aspx (accessed on 5 July

JUSTNature-Activation of

nature-based solutions for a just

low-carbon transition (2021-2026):

activation of $\mathrm{NbS}$ by ensuring a just

transition to low-carbon cities, based

on the principle of the right to

$10,246,806$

ecological space.

https:/ / cordis.europa.eu/ project/

id/101003757 (accessed on 5 July

2021)
SI/DE, MK, ES,

BE, EL, HR, IT,

UK, HU, SI, AT,

$\mathrm{NL}, \mathrm{PO} / 23$

Cities/Europe Air pollution,

GHG emission

NA

partners (13

countries)

IT/DE, EL, MT,

$\mathrm{HU}, \mathrm{BE}, \mathrm{IE}, \mathrm{NL}$

Cities/Europe change, GHG NA

emissions

(8 countries)
NA 


\section{Appendix B}

Table A2. Indicators and methods to be used to measure NbS impact.

\begin{tabular}{|c|c|c|c|c|}
\hline Impact Category/Challenges Addressed & Indicator & Unit & $\begin{array}{l}\text { Examples of Methods of } \\
\text { Assessment }\end{array}$ & Key References \\
\hline \multirow{6}{*}{ Environment } & \multirow[t]{3}{*}{$\begin{array}{l}\text { Carbon storage and sequestration } \\
\text { in vegetation and soil }\end{array}$} & $\begin{array}{l}\mathrm{t} C / \text { year (tons of carbon } \\
\text { removed or stored per area } \\
\text { per year) }\end{array}$ & $\begin{array}{l}\text { Using ground-based forest growth } \\
\text { rates, housing density data, } \\
\text { satellite-derived land cover and } \\
\text { tree canopy cover maps. }\end{array}$ & [135] \\
\hline & & $\begin{array}{l}\mathrm{t} \text { (total amount of carbon } \\
\text { (tons) stored in vegetation) }\end{array}$ & $\begin{array}{l}\text { Calculating above-ground trees } \\
\text { and herbaceous vegetation } \\
\text { biomass, and then transforming } \\
\text { biomass to a carbon storage. }\end{array}$ & [136] \\
\hline & & $\mathrm{Mg} / \mathrm{ha}$ & $\begin{array}{l}\text { Allometric forest models of carbon } \\
\text { sequestration, developed using } \\
\text { proxy data obtained from Lidar } \\
\text { data. }\end{array}$ & [132] \\
\hline & $\begin{array}{l}\text { Net carbon sequestration by urban } \\
\text { forests (including GHG emissions } \\
\text { from maintenance activities) }\end{array}$ & $\mathrm{tCha}^{-1} \mathrm{yr}^{-1}$ & $\begin{array}{l}\text { Numerical methods calculating or } \\
\text { estimating the interactions between } \\
\text { vegetation and pollutants at the } \\
\text { micro-scale allometric equations } \\
\text { that predict vegetation growth, } \\
\text { Forest Inventory Analysis. }\end{array}$ & [137] \\
\hline & $\begin{array}{l}\text { Reduced energy demand for } \\
\text { heating and cooling }\end{array}$ & $\begin{array}{l}\mathrm{t} \mathrm{CO}_{2} / \text { year }\left(\mathrm{CO}_{2} \text { emissions }\right. \\
\text { reduced per year })\end{array}$ & $\begin{array}{l}\text { With reference to a baseline } \\
\text { situation, the energy } \\
\text { not consumed can be accounted for } \\
\text { as a } \\
\text { reduction of } \mathrm{CO}_{2} \text { emissions. }\end{array}$ & [138] \\
\hline & $\begin{array}{l}\text { Annual amount of pollutants } \\
\text { captured and removed by } \\
\text { vegetation }\end{array}$ & $\begin{array}{l}\mathrm{t} \text { air pollutant(s) per } \\
\mathrm{ha}^{-1} / \text { year }\end{array}$ & $\begin{array}{l}\text { "Tiwary method", map air } \\
\text { purification using } \\
\text { spatially explicit data on ecosystem } \\
\text { types and } \\
\text { characteristics (particularly LAI), } \\
\text { and pollution } \\
\text { distribution, Forest Inventory } \\
\text { Analysis. }\end{array}$ & [139] \\
\hline
\end{tabular}


Table A2. Cont.

\begin{tabular}{|c|c|c|c|c|}
\hline Impact Category/Challenges Addressed & Indicator & Unit & $\begin{array}{l}\text { Examples of Methods of } \\
\text { Assessment }\end{array}$ & Key References \\
\hline \multirow{6}{*}{ Physical } & $\begin{array}{l}\text { Nutrient abatement, abatement of } \\
\text { pollutants }\end{array}$ & $\%$ of mass removal & $\begin{array}{l}\text { (Laboratory) experiment } \\
\text { measuring of water } \\
\text { quality, estimation of } \\
\text { biomass/abatement } \\
\text { capacity across different vegetation } \\
\text { types. } \\
\text { Estimation of biomass across } \\
\text { different vegetation } \\
\text { types. }\end{array}$ & [140] \\
\hline & Increased evapotranspiration & ET & $\begin{array}{l}\text { Estimation based of coefficients for } \\
\text { plant types }\end{array}$ & [141] \\
\hline & \multirow[t]{2}{*}{$\begin{array}{l}\text { Temperature reduction in urban } \\
\text { areas }\end{array}$} & \multirow[t]{2}{*}{$\min$ and $\max \mathrm{C}^{\circ} /$ day } & $\begin{array}{l}\text { Measurement (modeling) of day } \\
\text { and night mean, max and min. } \\
\text { temperatures, with respect to } \\
\text { baseline values }\left({ }^{\circ} \mathrm{C}\right)\end{array}$ & [142] \\
\hline & & & $\begin{array}{l}\text { Measures of human comfort, e.g., } \\
\text { ENVIMET PET (Personal } \\
\text { Equivalent Temperature), or PMV } \\
\text { (Predicted Mean Vote) }\end{array}$ & [143] \\
\hline & Heatwave risks & persons/ha & $\begin{array}{l}\text { Number of persons living in areas } \\
\text { with } x \text { number of day } \\
\text { sabove threshold day }\left(>35^{\circ} \mathrm{C}\right) \text { and } \\
\text { night temperatures }\left(>20^{\circ} \mathrm{C}\right) \text {. } \\
\text { Temperature thresholds defining } \\
\text { risk are slightly varying across } \\
\text { regions, source: local health } \\
\text { information systems. }\end{array}$ & {$[144,145]$} \\
\hline & infiltration capacities & $\mathrm{mm} / \mathrm{h}$ & $\begin{array}{l}\text { Surface and extent of flooded areas, } \\
\text { analysis of } \\
\text { soil and vegetation characteristics }\end{array}$ & [146] \\
\hline
\end{tabular}


Table A2. Cont.

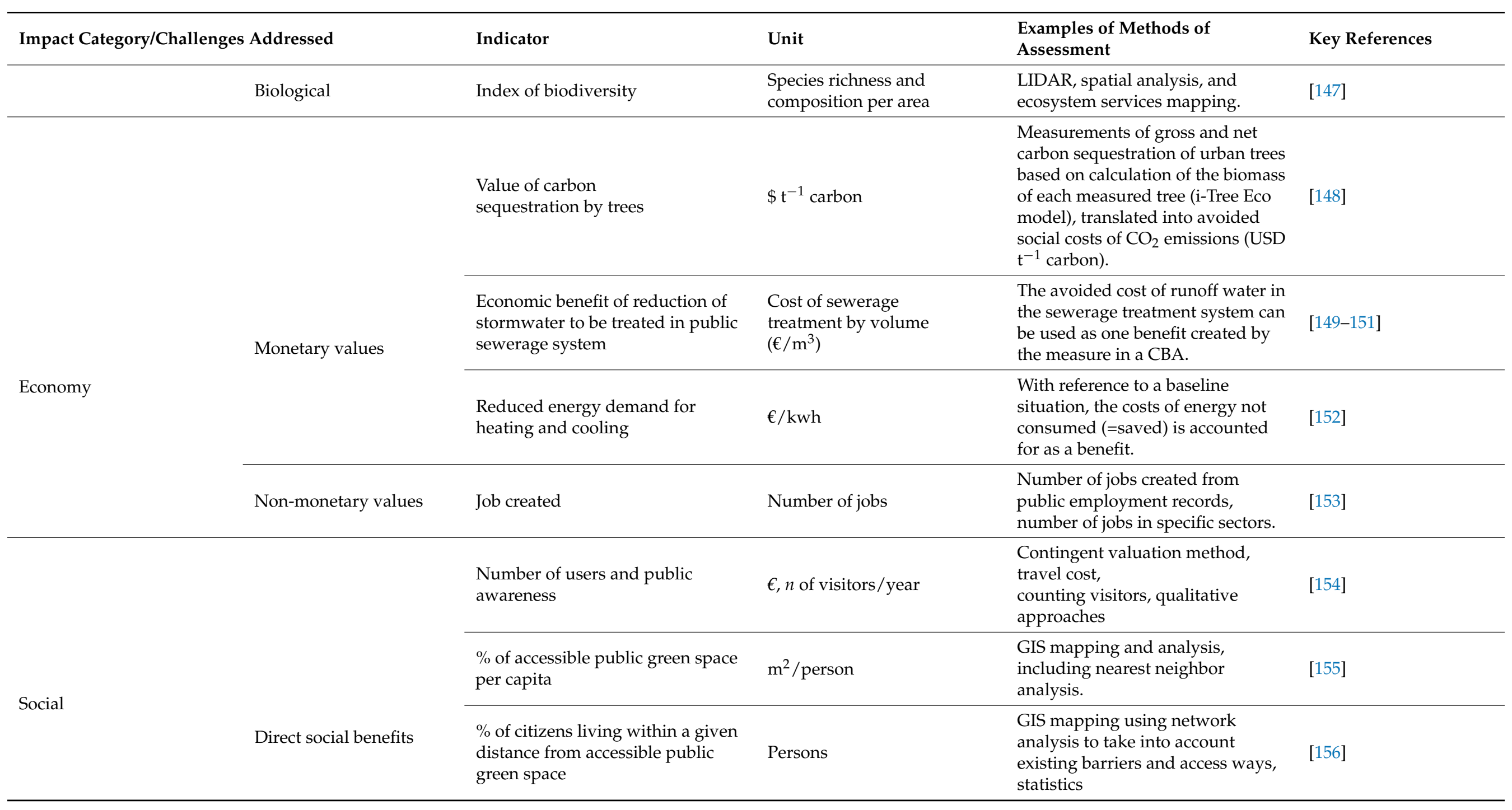


Table A2. Cont.

\begin{tabular}{|c|c|c|c|c|}
\hline Impact Category/Challenges Addressed & Indicator & Unit & $\begin{array}{l}\text { Examples of Methods of } \\
\text { Assessment }\end{array}$ & Key References \\
\hline & $\begin{array}{l}\text { The availability and distribution of } \\
\text { different types of parks and/or } \\
\text { ecosystem services with respect to } \\
\text { specific individual or household } \\
\text { socioeconomic profiles and } \\
\text { landscape design. }\end{array}$ & $\begin{array}{l}\text { e.g., mean distance (or time to } \\
\text { reach) parks per inhabitant. }\end{array}$ & $\begin{array}{l}\text { Statistics GIS, definition of criteria } \\
\text { for park types } \\
\text { index for spatial distribution, } \\
\text { network analysis using GIS for } \\
\text { assessing accessibility of parks. }\end{array}$ & [157] \\
\hline & $\begin{array}{l}\text { Security against violent assault, } \\
\text { including indicators of crime } \\
\text { bytime of day. }\end{array}$ & No. of cases/year & $\begin{array}{l}\text { Statistics and perceived levels of } \\
\text { crime and safety. }\end{array}$ & [158] \\
\hline & $\begin{array}{l}\text { Being able to participate effectively } \\
\text { in political choices that govern } \\
\text { one's life, including indicators on } \\
\text { level and quality of public } \\
\text { participation in environmental } \\
\text { management. }\end{array}$ & $\begin{array}{l}\text { Number of } \\
\text { connection/threshold } \\
\text { for the definition of } \\
\text { sufficient levels of } \\
\text { connections }\end{array}$ & $\begin{array}{l}\text { Actor-Network Analysis to better } \\
\text { understanding } \\
\text { how different stakeholders can bias } \\
\text { management } \\
\text { towards certain ecosystem services. }\end{array}$ & [159] \\
\hline Physiological benefits & $\begin{array}{l}\text { Structural aspects-family and } \\
\text { friendship ties }\end{array}$ & $\begin{array}{l}\text { Number of } \\
\text { connection/threshold } \\
\text { for the definition of } \\
\text { sufficient levels of } \\
\text { connections }\end{array}$ & $\begin{array}{l}\text { Network analysis, survey, } \\
\text { questionnaires and } \\
\text { interviews, sampling }\end{array}$ & [160] \\
\hline & $\begin{array}{l}\text { Chronic stress and stress-related } \\
\text { diseases as shown in cortisol levels }\end{array}$ & $\begin{array}{l}\text { Cortisol slope and } \\
\text { average cortisol } \\
\text { levels }\end{array}$ & $\begin{array}{l}\text { Measured through repeated } \\
\text { salivary and/or hair } \\
\text { cortisol sampling assessing effects } \\
\text { of nature } \\
\text { experiences through assignment of } \\
\text { participants to } \\
\text { particular exercises (walk in nature } \\
\text { for a certain } \\
\text { time) followed by psychological } \\
\text { assessments and } \\
\text { assessments of affective and } \\
\text { cognitive functioning }\end{array}$ & [161] \\
\hline
\end{tabular}


Table A2. Cont.

\begin{tabular}{|c|c|c|c|c|}
\hline Impact Category/Challenges Addressed & Indicator & Unit & $\begin{array}{l}\text { Examples of Methods of } \\
\text { Assessment }\end{array}$ & Key References \\
\hline & $\begin{array}{l}\text { Increase in number and percentage } \\
\text { of people being physically active } \\
\text { (minimum } 30 \mathrm{~min}, 3 \text { times per } \\
\text { week) }\end{array}$ & $\begin{array}{l}\text { Days with physical } \\
\text { activity }(\mathrm{n})\end{array}$ & $\begin{array}{l}\text { Questionnaires to ask for the } \\
\text { number of days on } \\
\text { which physical activity (of } \\
\text { sufficient exertion to } \\
\text { raise breathing rate) reached or } \\
\text { exceeded } 30 \text { min } \\
\text { (e.g., over the past } 4 \text { weeks) } \\
\text { (self-reporting) }\end{array}$ & [162] \\
\hline & $\begin{array}{l}\text { Reduced percentage of obese } \\
\text { people and children }\end{array}$ & $\%$ & $\begin{array}{l}\text { Baseline needed for rate of obesity } \\
\text { in } \\
\text { population/eventually: reference } \\
\text { to median city } \\
\text { / regional/national percentage }\end{array}$ & [163] \\
\hline & $\begin{array}{l}\text { Reduction in overall mortality and } \\
\text { increased lifespan }\end{array}$ & $\begin{array}{l}\text { Number of deaths per } \\
1000 \text { individuals per } \\
\text { year }\end{array}$ & $\begin{array}{l}\text { Assessing effects of nature } \\
\text { experiences through } \\
\text { assignment of participants to } \\
\text { exercises } \\
\text { (e.g., walk in nature for a certain } \\
\text { time) followed by } \\
\text { psychological assessments and } \\
\text { assessments of } \\
\text { affective and cognitive functioning. }\end{array}$ & [164] \\
\hline & $\begin{array}{l}\text { Reduction in number of } \\
\text { cardiovascular morbidity and } \\
\text { mortality events }\end{array}$ & $\begin{array}{l}\text { Number of deaths per } \\
1000 \text { individuals per } \\
\text { year; morbidity scores }\end{array}$ & $\begin{array}{l}\text { Composite tools for measuring } \\
\text { health and detailed psychometric } \\
\text { testing. }\end{array}$ & {$[164,165]$} \\
\hline
\end{tabular}




\section{References}

1. Ershad Sarabi, S.; Han, Q.; Romme, A.G.L.; de Vries, B.; Wendling, L. Key Enablers of and Barriers to the Uptake and Implementation of Nature-Based Solutions in Urban Settings: A Review. Resources 2019, 8, 121. [CrossRef]

2. Chen, X.; de Vries, S.; Assmuth, T.; Dick, J.; Hermans, T.; Hertel, O.; Jensen, A.; Jones, L.; Kabisch, S.; Lanki, T.; et al. Research challenges for cultural ecosystem services and public health in (peri-)urban environments. Sci. Total. Environ. 2019, 651, 2118-2129. [CrossRef] [PubMed]

3. BBVA. Urbanization Report-European Urbanization Trends. Available online: https://www.bbvaresearch.com/wp-content/ uploads/2016/12/European-urbanization-trends_.pdf (accessed on 10 July 2021).

4. UN, Department of Economic and Social Affairs, Population Division. 2018 Revision of World Urbanization Prospects; UN: New York, NY, USA, 2019; Available online: https: / / population.un.org/wup (accessed on 13 July 2021).

5. UN-Habitat. The New Urban Agenda; UN-Habitat: Nairobi, Kenya, 2020; ISBN 978-92-1-132869-1.

6. UNDP. Goal 11-Sustainable Cities and Communities. Available online: https://www.undp.org/sustainable-developmentgoals\#sustainable-cities-and-communities (accessed on 11 July 2021).

7. Nesshöver, C.; Assmuth, T.; Irvine, K.N.; Rusch, G.M.; Waylen, K.A.; Delbaere, B.; Haase, D.; Jones-Walters, L.; Keune, H.; Kovacs, E.; et al. The science, policy and practice of nature-based solutions: An interdisciplinary perspective. Sci. Total. Environ. 2017, 579, 1215-1227. [CrossRef]

8. IUCN. WCC-2016-Res-069-EN-Defining Nature-based Solutions. Available online: https://www.iucn.org/sites/dev/files/ content/documents/wcc_2016_res_069_en.pdf (accessed on 28 September 2021).

9. EC. Towards an EU Research and Innovation Policy Agenda for Nature-Based Solutions E re-Naturing Cities-Final Report of the Horizon 2020 Expert Group on Nature-Based Solutions and Re-Naturing Cities; Publications Office of the European Union: Luxembourg, 2015; ISBN 978-92-79-46051-7.

10. Cohen-Shacham, E.; Andrade, A.; Dalton, J.; Dudley, N.; Jones, M.; Kumar, C.; Maginnis, S.; Maynard, S.; Nelson, C.R.; Renaud, F.G.; et al. Core principles for successfully implementing and upscaling Nature-based Solutions. Environ. Sci. Policy 2019, 98, 20-29. [CrossRef]

11. Clemants, S.E.; Marinelli, J.; Moore, G.; Peters, E. Green Roofs and Biodiversity. The Center for Urban Restoration Ecology: New York. URBANhabitats 2006, 4, 1-144.

12. EFB. White Paper-Greener Cities in Europe. Available online: https://efb-greenroof.eu/wp-content/uploads/2016/12/efb_ whitepaper_2015.pdf (accessed on 10 July 2021).

13. Sandifer, P.A.; Sutton-Grier, A.E.; Ward, B.P. Exploring connections among nature, biodiversity, ecosystem services, and human health and well-being: Opportunities to enhance health and biodiversity conservation. Ecosyst. Serv. 2015, 12, 1-15. [CrossRef]

14. Haase, A. The Contribution of Nature-Based Solutions to Socially Inclusive Urban Development- Some Reflections from a Social-environmental Perspective. In Nature-Based Solutions to Climate Change Adaptation in Urban Areas: Linkages between Science, Policy and Practice; Kabisch, N., Korn, H., Stadler, J., Bonn, A., Eds.; Springer International Publishing: Cham, Switzerland, 2017; pp. 221-236. [CrossRef]

15. Naumann, S.; Kaphengst, T.; McFarland, K.; Jutta, S. Nature-Based Approaches for Climate Change Mitigation and AdaptationThe Challenges of Climate Change-Partnering with Nature; German Federal Agency for Nature Conservation (BfN), Ecologic Institute: Bonn, Germany, 2014.

16. Raymond, C.M.; Berry, P.; Breil, M.; Nita, M.R.; Kabisch, N.; de Bel, M.; Enzi, V.; Frantzeskaki, N.; Geneletti, D.; Cardinaletti, M.; et al. An Impact Evaluation Framework to Support Planning and Evaluation of Nature-based Solutions Projects. Report Prepared by the EKLIPSE Expert Working Group on Nature-Based Solutions to Promote Climate Resilience in Urban Areas; Centre for Ecology \& Hydrology: Wallingford, UK, 2017.

17. Somarakis, G.; Stagakis, S.; Chrysoulakis, N. (Eds.) ThinkNature Nature-Based Solutions Handbook; European Union: Brussels, Belgium, 2019. [CrossRef]

18. IUCN. IUCN Global Standard for Nature-Based Solutions: A User-Friendly Framework for the Verification, Design and Scaling Up of NbS, 1st ed.; IUCN: Gland, Switzerland, 2020. [CrossRef]

19. Oppla. Oppla-EU Repository of Nature-Based Solutions. Available online: https:/ / oppla.eu (accessed on 28 September 2021).

20. Guo, Z.; Xiao, X.; Li, D. An assessment of ecosystem services: Water flow regulation and hydroelectric power production. Ecol. Appl. 2000, 10, 925-936. [CrossRef]

21. Singh, R.A.; Kim, H.J.; Kim, J.; Yang, S.; Jeong, H.E.; Suh, K.Y.; Yoon, E.-S. A biomimetic approach for effective reduction in micro-scale friction by direct replication of topography of natural water-repellent surfaces. J. Mech. Sci. Technol. 2007, 21, 624-629. [CrossRef]

22. World Bank. Biodiversity, Climate Change, and Adaptation: Nature-Based Solutions from the World Bank Portfolio; World Bank: Washington, DC, USA, 2008.

23. Mittermeier, R.A.; Totten, M.; Pennypacker, L.L.; Boltz, F. A Climate for Life: Meeting the Global Challenge, 1st ed.; International League of Conservation Photographers: Arlington, VA, USA, 2008.

24. Dudley, N.; Stolton, S.; Belokurov, A.; Krueger, L.; Lopoukhine, N.; MacKinnon, K.; Sandwith, T.; Sekhran, N. (Eds.) Natural Solutions: Protected Areas Helping People Cope with Climate Change; IUCN-WCPA: Gland, Switzerland; TNC: New York, NY, USA; UNDP: New York, NY, USA; WCS: New York, NY, USA; The World Bank: Washington, DC, USA; WWF: Gland, Switzerland, 2010. 
25. IUCN. The IUCN Programme 2013-2016-Adopted by the IUCN World Conservation Congress, September 2012; IUCN: Gland, Switzerland, 2012.

26. IUCN. Nature-Based Solutions in Mesoamerica and the Paris Agreement. Available online: https://www.iucn.org/sites/dev/ files/content/documents/s3_governance_02_nbs_and_the_paris_agreement_en_web.pdf (accessed on 16 July 2021).

27. Cohen-Shacham, E.; Walters, G.; Janzen, C.; Maginnis, S. Nature-Based Solutions to Address Global Societal Challenges; IUCN: Gland, Switzerland, 2016; p. 97. [CrossRef]

28. IUCN. No time to lose-make full use of nature-based solutions in the post-2012 climate change regime. In Proceedings of the Fifteenth session of the Conference of the Parties to the United Nations Framework Convention on Climate Change (COP15), Copenhagen, Denmark, 7-18 December 2009.

29. EC. Horizon 2020 Work Programme 2016-2017-12. Climate Action, Environment, Resource Efficiency and Raw Materials; EC: Brussels, Belgium, 2017.

30. EC. A European Green Deal—Striving to Be the First Climate-Neutral Continent. Available online: https://ec.europa.eu/info/ strategy / priorities-2019-2024/european-green-deal_en (accessed on 11 July 2021).

31. EC. Horizon Europe Calls. Available online: https://ec.europa.eu/info/funding-tenders/opportunities/portal/screen/home (accessed on 10 July 2021).

32. Sutton-Grier, A.E.; Gittman, R.K.; Arkema, K.K.; Bennett, R.O.; Benoit, J.; Blitch, S.; Burks-Copes, K.A.; Colden, A.; Dausman, A.; DeAngelis, B.M.; et al. Investing in Natural and Nature-Based Infrastructure: Building Better Along Our Coasts. Sustainability 2018, 10, 523. [CrossRef]

33. FEMA. Engineering with Nature: Alternative Techniques to Riprap Bank Stabilization; FEMA: Washington, DC, USA, 2009.

34. EC. The EU and Nature-Based Solutions. Available online: https://ec.europa.eu/info/research-and-innovation/research-area/ environment/nature-based-solutions_en (accessed on 10 July 2021).

35. Maes, J.; Jacobs, S. Nature-Based Solutions for Europe's Sustainable Development. Conserv. Lett. 2017, 10, 121-124. [CrossRef]

36. IUCN. Synopsis of Consultation and Feedback Process for the Development of the IUCN Global Standard for Nature-Based Solutions. Available online: https://www.iucn.org/theme/nature-based-solutions/resources/iucn-global-standard-nbs (accessed on 16 July 2021).

37. EC. Nature-Based Solutions. Available online: https://rea.ec.europa.eu/funding-and-grants/horizon-europe-cluster-6-foodbioeconomy-natural-resources-agriculture-and-1_en (accessed on 29 September 2021).

38. Naumann, S. The Use of Ecosystem-Based Approaches to Climate Change Adaptation and Mitigation: Barriers and Success Factors. Available online: https:/ /www.ecologic.eu/sites/default/files/presentation/2013/ECCA-Conference-2013-EbA-EbMNaumann_0.pdf (accessed on 23 August 2021).

39. Secretariat of the Convention on Biological Diversity. CBD Guidelines—the Ecosystem Approach; Secretariat of the Convention on Biological Diversity: Montreal, QC, Canada, 2004; p. 50.

40. Mitsch, W.J. Ecological engineering: A new paradigm for engineers and ecologists. In Engineering within Ecological Constraints; Schulze, P.C., Ed.; National Academy Press, Washington: Washington, DC, USA, 1996; pp. 111-128.

41. Bergen, S.D.; Bolton, S.M.; Fridley, J.L. Design principles for ecological engineering. Ecol. Eng. 2001, 18, 201-210. [CrossRef]

42. Benedict, M.A.; McMahon, E.T.; Mark, A. Green Infrastructure: Linking Landscapes and Communities; Island Press: Washington, DC, USA, 2006

43. EC. Green Infrastructure (GI)_Enhancing Europe's Natural Capital. Available online: https:/ / eur-lex.europa.eu/resource.html? uri=cellar:d41348f2-01d5-4abe-b817-4c73e6f1b2df.0014.03/DOC_1\&format=PDF (accessed on 11 July 2021).

44. Grellier, J.; White, M.P.; Albin, M.; Bell, S.; Elliott, L.R.; Gascón, M.; Gualdi, S.; Mancini, L.; Nieuwenhuijsen, M.J.; Sarigiannis, D.A.; et al. BlueHealth: A study programme protocol for mapping and quantifying the potential benefits to public health and well-being from Europe's blue spaces. BMJ Open 2017, 7, e016188. [CrossRef] [PubMed]

45. Voskamp, I.M.; Van de Ven, F.H.M. Planning support system for climate adaptation: Composing effective sets of blue-green measures to reduce urban vulnerability to extreme weather events. Build. Environ. 2015, 83, 159-167. [CrossRef]

46. Ghofrani, Z.S.V.; Faggian, R. A Comprehensive Review of Blue-Green Infrastructure Concepts. Int. J. Environ. Sustain. 2017, 6, 15-36. [CrossRef]

47. Smith, R.D.; Maltby, E. Using the Ecosystem Approach to Implement the Convention on Biological Diversity: Key Issues and Case Studies (Ecosystem Management); Secretariat of the Convention on Biological Diversity: Montreal, QC, Canada, 2003.

48. Thompson, I.; Mackey, B.; McNulty, S.; Mosseler, A. Forest Resilience, Biodiversity, and Climate Change. A synthesis of the Biodiversity/Resilience/Stability Relationship in Forest Ecosystems; Secretariat of the Convention on Biological Diversity: Montreal, QC, Canada, 2009; p. 67.

49. Colls, A.; Ash, N.; Ikkala Nyman, N. Ecosystem-Based Adaptation: A Natural Response to Climate Change; IUCN: Gland, Switzerland, 2009.

50. Andrade Pérez, A.; Herrera Fernández, B.; Cazzolla Gatti, R. (Eds.) Building Resilience to Climate Change: Ecosystem-Based Adaptation and Lessons from the Field; IUCN: Gland, Switzerland, 2010.

51. Google Trends. Available online: https://trends.google.com/trends (accessed on 6 July 2021).

52. UNFCC. United Nations Framework Convention on Climate Change. Available online: https://unfccc.int (accessed on 5 July 2021).

53. CBD. The Convention on Biological Diversity. Available online: https:/ / www.cbd.int (accessed on 1 July 2021). 
54. UNDRR. The UN Sendai Framework for Disaster Risk Reduction. Available online: https://www.undrr.org (accessed on 2 July 2021).

55. The World Economic Forum Webportal. Available online: https://www.weforum.org (accessed on 3 July 2021).

56. UNEP. Available online: https:/ / www.unep.org/environmentassembly (accessed on 4 July 2021).

57. CBD. Mainstreaming and the Integration of Biodiversity across Relevant Sectors, and Further Implications of the 2030 Agenda for Sustainable Development and of Other Relevant International Processes for the Future Work of the Convention. In Proceedings of the 13th Conference of the Parties to the Convention on Biological Diversity, Cancun, Mexico, 4-17 December 2016.

58. CBD. Voluntary Guidelines for the Design and Effective Implementation of Ecosystem-Based Approaches to Climate Change Adaptation and Disaster Risk Reduction and Supplementary Information; CBD: Montreal, QC, Canada, 2019; p. 156.

59. IPBES. Global Assessment Report of the Intergovernmental Science-Policy Platform on Biodiversity and Ecosystem Services; IPBES secretariat: Bonn, Germany, 2019; p. 1144.

60. CBD. Update of the Zero Draft of the Post-2020 Global Biodiversity Framework; Secretariat of the Convention on Biological Diversity: Montreal, QC, Canada, 2020.

61. UNDRR. Nature-Based Solutions for Disaster Risk Reduction-Words into Action; UNDRR: Geneva, Switzerland, 2021 ; p. 259.

62. UNEP. The Nature-Based Solutions for Climate Manifesto. In Proceedings of the UN Climate Action Summit 2019, New York, NY, USA, 21-23 September 2019; p. 2.

63. EC. Joint Declaration on the EU-China Partnership on Urbanisation. Available online: https://eeas.europa.eu/headquarters/ headquarters-homepage_en/16132/\%20EU-China\%20Joint\%20Declaration\%20on\%20Urbanisation (accessed on 7 July 2021).

64. WHO. Health as the Pulse of the New Urban Agenda. In Proceedings of the United Nations Conference on Housing and Sustainable Urban Development, Quito, Ecuador, 17-20 October 2016; World Health Organization: Geneva, Switzerland, 2016.

65. Faivre, N.; Fritz, M.; Freitas, T.; de Boissezon, B.; Vandewoestijne, S. Nature-Based Solutions in the EU: Innovating with nature to address social, economic and environmental challenges. Environ. Res. 2017, 159, 509-518. [CrossRef]

66. Dudley, N.; Ali, N.; Kettunen, M.; MacKinnon, K. Protected areas and the sustainable development goals. PARKS 2017, 23, 9-12. [CrossRef]

67. Vasseur, L.; Horning, D.; Thornbush, M.; Cohen-Shacham, E.; Andrade, A.; Barrow, E.; Edwards, S.R.; Wit, P.; Jones, M. Complex problems and unchallenged solutions: Bringing ecosystem governance to the forefront of the UN sustainable development goals. Ambio 2017, 46, 731-742. [CrossRef]

68. Gómez Martín, E.; Giordano, R.; Pagano, A.; van der Keur, P.; Máñez Costa, M. Using a system thinking approach to assess the contribution of nature based solutions to sustainable development goals. Sci. Total. Environ. 2020, 738, 139693. [CrossRef]

69. Hanson, H.I.; Wickenberg, B.; Alkan Olsson, J. Working on the boundaries-How do science use and interpret the nature-based solution concept? Land Use Policy 2020, 90, 104302. [CrossRef]

70. UN. Transforming Our World: The 2030 Agenda for Sustainable Development. Available online: https://www.un.org/ga/ search/view_doc.asp?symbol=A/RES/70/1\&Lang=E (accessed on 11 July 2021).

71. EC. CORDIS-EU Research Results. Available online: https://cordis.europa.eu/search (accessed on 24 August 2021).

72. EC. Horizon 2020 Work Programme 2018-2020-19. General Annexes; EC: Brussels, Belgium, 2019; p. 37.

73. EC. FP7 in Brief-How to Get Involved in the EU 7th Framework Programme for Research: A pocket guide for newcomers. Office for Official Publications of the European Communities: Luxembourg, 2007; p. 36.

74. ERC. ERC Work Programme 2018; ERC: Brussels, Belgium, 2017; p. 62.

75. EC. Commission Welcomes the Adoption of $€ 373$ Billion Cohesion Policy Legislative Package 2021-2027. Available online: https: / / ec.europa.eu/commission/presscorner/detail/en/ip_21_3058 (accessed on 12 July 2021).

76. EC. InvestEU. Available online: https://europa.eu/investeu/home_en (accessed on 14 July 2021).

77. EC. LIFE Programme. Available online: https://cinea.ec.europa.eu/life_en (accessed on 13 July 2021).

78. Gao, J.; Wang, Y.; Zou, C.; Xu, D.; Lin, N.; Wang, L.; Zhang, K. China's ecological conservation redline: A solution for future nature conservation. Ambio 2020, 49, 1519-1529. [CrossRef]

79. Shen, D. The River and Lake Chief System. In Water Resources Management of the People's Republic of China: Framework, Reform and Implementation; Shen, D., Ed.; Springer International Publishing: Cham, Switzerland, 2021; pp. 241-252. [CrossRef]

80. Coenen, J.; Bager, S.; Meyfroidt, P.; Newig, J.; Challies, E. Environmental Governance of China's Belt and Road Initiative. Environ. Policy Gov. 2021, 31, 3-17. [CrossRef]

81. Wang, H.; He, M.; Ran, N.; Xie, D.; Wang, Q.; Teng, M.; Wang, P. China's Key Forestry Ecological Development Programs: Implementation, Environmental Impact and Challenges. Forests 2021, 12, 101.

82. Hai, R.; Shaolin, P. The Practice of Ecological Restoration in China: A Brief History and Conference Report. Ecol. Restor. 2003, 21, 122-125. [CrossRef]

83. FMPRC. Building a Shared Future for All Life on Earth:China in Action-Position Paper of the People's Republic of China for the United Nations Summit on Biodiversity. Available online: https://www.fmprc.gov.cn/mfa_eng/wjdt_665385/2649_665393/t181 6598.shtml (accessed on 15 July 2021).

84. Yang, L.; Li, X. Exploration and Analysis on the way of building green lifestyle. IOP Conf. Ser. Earth Environ. Sci. 2020, 615, 012037. [CrossRef] 
85. Harris, M. China's sponge cities: Soaking up water to reduce flood risks. The Guardian 2015, ISSN 0261-3077. Available online: https:/ / www.theguardian.com/sustainable-business/2015/oct/01/china-sponge-cities-los-angeles-water-urban-designdrought-floods-urbanisation-rooftop-gardens (accessed on 29 September 2021).

86. Yu, K.L.D.; Yuan, H.; Fu, W.; Qiao, Q.; Wang, S. SPONGE CITy: THEORY AND PRACTICE. Plan. Stud. 2015, 39, 26-35.

87. Biswas, A.K.; Hartley, K. China's 'Sponge Cities' Aim to Re-Use 70\% of Rainwater-Here's How. The Conversation 2018. Available online: https:// theconversation.com/chinas-sponge-cities-aim-to-re-use-70-of-rainwater-heres-how-83327 (accessed on 28 September 2021).

88. Su, Y.; Qin, S.; Zhao, Y.; Trinkaus, S.D.; Dang, J. Operation and maintenance challenges in China "Sponge City" program. J. Civ. Eng. Archit. 2020, 14, 532-536. [CrossRef]

89. Yu, K. "SPONGE CITy": Theory and Practice. Geography. 2015. Available online: https:/ / en.cnki.com.cn/Article_en/CJFDTotalCSGH201506009.htm (accessed on 28 September 2021).

90. Eggermont, H.; Balian, E.; Azevedo, J.M.N.; Beumer, V.; Brodin, T.; Claudet, J.; Fady, B.; Grube, M.; Keune, H.; Lamarque, P.; et al. Nature-based Solutions: New Influence for Environmental Management and Research in Europe. GAIA-Ecol. Perspect. Sci. Soc. 2015, 24, 243-248. [CrossRef]

91. BiodivERsA Home. Available online: https:/ / www.biodiversa.org (accessed on 17 July 2021).

92. Dumitru, A.; Wendling, L. (Eds.) Evaluating the Impact of Nature-Based Solutions-A Handbook for Practitioners, 1st ed.; Publications Office of the European Union: Luxembourg, 2021. [CrossRef]

93. Kolb, A.; Diekmann, M. Effects of environment, habitat configuration and forest continuity on the distribution of forest plant species. J. Veg. Sci. 2004, 15, 199-208. [CrossRef]

94. Potchter, O.; Cohen, P.; Bitan, A. Climatic behavior of various urban parks during hot and humid summer in the mediterranean city of Tel Aviv, Israel. Int. J. Climatol. 2006, 26, 1695-1711. [CrossRef]

95. Chen, L.; Zhang, Z.; Li, Z.; Tang, J.; Caldwell, P.; Zhang, W. Biophysical control of whole tree transpiration under an urban environment in Northern China. J. Hydrol. 2011, 402, 388-400. [CrossRef]

96. Stovin, V.; Vesuviano, G.; Kasmin, H. The hydrological performance of a green roof test bed under UK climatic conditions. J. Hydrol. 2012, 414-415, 148-161. [CrossRef]

97. Munang, R.; Thiaw, I.; Alverson, K.; Liu, J.; Han, Z. The role of ecosystem services in climate change adaptation and disaster risk reduction. Curr. Opin. Environ. Sustain. 2013, 5, 47-52. [CrossRef]

98. Narayan, S.; Beck, M.W.; Reguero, B.G.; Losada, I.J.; van Wesenbeeck, B.; Pontee, N.; Sanchirico, J.N.; Ingram, J.C.; Lange, G.-M.; Burks-Copes, K.A. The Effectiveness, Costs and Coastal Protection Benefits of Natural and Nature-Based Defences. PLoS ONE 2016, 11, e0154735. [CrossRef] [PubMed]

99. Enzi, V.; Cameron, B.; Dezsényi, P.; Gedge, D.; Mann, G.; Pitha, U. Nature-Based Solutions and Buildings-The Power of Surfaces to Help Cities Adapt to Climate Change and to Deliver Biodiversity. In Nature-Based Solutions to Climate Change Adaptation in Urban Areas: Linkages between Science, Policy and Practice; Kabisch, N., Korn, H., Stadler, J., Bonn, A., Eds.; Springer International Publishing: Cham, Switzerland, 2017; pp. 159-183. [CrossRef]

100. Moos, C.; Bebi, P.; Schwarz, M.; Stoffel, M.; Sudmeier-Rieux, K.; Dorren, L. Ecosystem-based disaster risk reduction in mountains. Earth-Sci. Rev. 2018, 177, 497-513. [CrossRef]

101. Xing, Y.; Jones, P.; Donnison, I. Characterisation of Nature-Based Solutions for the Built Environment. Sustainability 2017, 9 , 149. [CrossRef]

102. Kopsieker, L.; Gerritsen, E.; Stainforth, T.; Lucic, A.; Domingo, C.G.; Naumann, S.; Röschel, L.; Davis, M. Nature-Based Solutions and their Socio-Economic Benefits for Europe's Recovery: Enhancing the Uptake of Nature-Based Solutions Across EU Policies; Institute for European Environmental Policy: Brussels, Belgium, 2021; p. 19.

103. Thinknature. Platform for NBS. Available online: https://www.think-nature.eu/ (accessed on 18 July 2021).

104. Nature-Based Solutions Initiative. Available online: https:/ / www.naturebasedsolutionsinitiative.org (accessed on 19 July 2021).

105. Naturvation. Urban Nature Atlas. Available online: https:/ / naturvation.eu/atlas (accessed on 18 July 2021).

106. EEA. Data and Maps. Available online: https:/ / www.eea.europa.eu/data-and-maps (accessed on 18 July 2021).

107. EEA. Climate ADAPT—Sharing Adaptation Information Across EUROPE. Available online: https:// climate-adapt.eea.europa.eu (accessed on 18 July 2021).

108. JRC. Joint Research Centre Data Catalogue. Available online: https:/ / data.jrc.ec.europa.eu (accessed on 18 July 2021 ).

109. Copernicus. Europe's Eyes on Earth. Available online: https://www.copernicus.eu/en (accessed on 18 July 2021).

110. Biodiversity Information System for EUROPE. Available online: https://biodiversity.europa.eu (accessed on 18 July 2021).

111. EU. WISE-Water Information System for Europe. Available online: https:/ / water.europa.eu (accessed on 18 July 2021).

112. EEA. Forest Information System for EUROPE. Available online: https: / / forest.eea.europa.eu (accessed on 18 July 2021 ).

113. Ferreira, V.; Barreira, A.P.; Loures, L.; Antunes, D.; Panagopoulos, T. Stakeholders' Engagement on Nature-Based Solutions: A Systematic Literature Review. Sustainability 2020, 12, 640. [CrossRef]

114. Frantzeskaki, N. Seven lessons for planning nature-based solutions in cities. Environ. Sci. Policy 2019, 93, 101-111. [CrossRef]

115. RewildingEurope. What Is Rewilding? Available online: https://rewildingeurope.com/what-is-rewilding-2 (accessed on 27 August 2021).

116. Making Europe a Wilder Place. Available online: https:/ / rewildingeurope.com/ (accessed on 27 August 2021). 
117. Debele, S.E.; Kumar, P.; Sahani, J.; Marti-Cardona, B.; Mickovski, S.B.; Leo, L.S.; Porcù, F.; Bertini, F.; Montesi, D.; Vojinovic, Z.; et al. Nature-based solutions for hydro-meteorological hazards: Revised concepts, classification schemes and databases. Environ. Res. 2019, 179, 108799. [CrossRef]

118. Potschin, M.; Kretsch, C.; Haines-Young, R.; Furman, E.; Berry, P.; Baró, F. Nature-based solutions. In OpenNESS Ecosystem Services Reference Book; Potschin, M., Jaz, K., Eds.; European Centre for Nature Conservation: Tilburg, The Netherlands, 2016.

119. Lafortezza, R.; Chen, J.; van den Bosch, C.K.; Randrup, T.B. Nature-based solutions for resilient landscapes and cities. Environ. Res. 2018, 165, 431-441. [CrossRef]

120. Davies, C.; Chen, W.Y.; Sanesi, G.; Lafortezza, R. The European Union roadmap for implementing nature-based solutions: A review. Environ. Sci. Policy 2021, 121, 49-67. [CrossRef]

121. Baig, S.; Rizvi, A.R.; Verdone, M. Ecosystem Based Adaptation: Knowledge Gaps in Making an Economic Case for Investing in Nature-Based Solutions for Climate Change; IUCN: Gland, Switzerland, 2015; p. 48.

122. Balian, E.; Eggermont, H.; Le Roux, X. Outputs of the Strategic Foresight Workshop "Nature-Based Solutions in a BiodivERsA Context"; Belgian Science Policy Office: Brussels, Belgium, 2014; p. 45.

123. Li, L.; Cheshmehzangi, A.; Chan, F.K.S.; Ives, C.D. Mapping the Research Landscape of Nature-Based Solutions in Urbanism. Sustainability 2021, 13, 3876.

124. EC. Nature-Based Solutions—State of the Art in EU-Funded Projects; Publications Office of the European Union: Luxembourg, 2020.

125. Doswald, N.; Munroe, R.; Roe, D.; Giuliani, A.; Castelli, I.; Stephens, J.; Möller, I.; Spencer, T.; Vira, B.; Reid, H. Effectiveness of ecosystem-based approaches for adaptation: Review of the evidence-base. Clim. Dev. 2014, 6, 185-201. [CrossRef]

126. Munang, R.; Andrews, J.; Alverson, K.; Mebratu, D. Harnessing Ecosystem-based Adaptation To Address the Social Dimensions of Climate Change. Environ. Sci. Policy Sustain. Dev. 2014, 56, 18-24. [CrossRef]

127. Wamsler, C.; Brink, E. Moving beyond short-term coping and adaptation. Environ. Urban. 2014, 26, 86-111. [CrossRef]

128. Wamsler, C.; Pauleit, S.; Zölch, T.; Schetke, S.; Mascarenhas, A. Mainstreaming Nature-Based Solutions for Climate Change Adaptation in Urban Governance and Planning. In Nature-Based Solutions to Climate Change Adaptation in Urban Areas: Linkages between Science, Policy and Practice; Kabisch, N., Korn, H., Stadler, J., Bonn, A., Eds.; Springer International Publishing: Cham, Switzerland, 2017; pp. 257-273. [CrossRef]

129. Seddon, N.; Chausson, A.; Berry, P.; Girardin, C.A.J.; Smith, A.; Turner, B. Understanding the value and limits of nature-based solutions to climate change and other global challenges. Philos. Trans. R. Soc. B Biol. Sci. 2020, 375, 20190120. [CrossRef]

130. Seddon, N.; Sengupta, S.; García-Espinosa, M.; Hauler, I.; Herr, D.; Rizvi, A.R. Nature-Based Solutions in Nationally Determined Contributions: Synthesis and Recommendations for Enhancing Climate Ambition and Action by 2020; IUCN: Gland, Switzerland, 2019; p. 48.

131. Raymond, C.M.; Frantzeskaki, N.; Kabisch, N.; Berry, P.; Breil, M.; Nita, M.R.; Geneletti, D.; Calfapietra, C. A framework for assessing and implementing the co-benefits of nature-based solutions in urban areas. Environ. Sci. Policy 2017, 77, 15-24. [CrossRef]

132. Giannico, V.; Lafortezza, R.; John, R.; Sanesi, G.; Pesola, L.; Chen, J. Estimating Stand Volume and Above-Ground Biomass of Urban Forests Using LiDAR. Remote. Sens. 2016, 8, 339. [CrossRef]

133. Hunt, A.; Bragg, R.; Stancliffe, R.; Williams, B.; Preston, S. Transforming Mental Health and Dementia with the Natural Environment, Conference Report 2017; The Center For Sustainable Healthcare: Oxford, UK, 2017.

134. Zhao, B. Nature-based solution-A New Ecological Term. Available online: https:/ / youtu.be/IUWWxNTQ1As (accessed on 28 June 2021).

135. Zheng, D.; Ducey, M.J.; Heath, L.S. Assessing net carbon sequestration on urban and community forests of northern New England, USA. Urban For. Urban Green. 2013, 12, 61-68. [CrossRef]

136. Davies, Z.G.; Edmondson, J.L.; Heinemeyer, A.; Leake, J.R.; Gaston, K.J. Mapping an urban ecosystem service: Quantifying above-ground carbon storage at a city-wide scale. J. Appl. Ecol. 2011, 48, 1125-1134. [CrossRef]

137. Nowak, D.J.; Greenfield, E.J.; Hoehn, R.E.; Lapoint, E. Carbon storage and sequestration by trees in urban and community areas of the United States. Environ Pollut. 2013, 178, 229-236. [CrossRef] [PubMed]

138. Akbari, H. Shade trees reduce building energy use and CO2 emissions from power plants. Environ Pollut. 2002, 116 (Suppl. S1), S119-S126. [CrossRef]

139. Manes, F.; Marando, F.; Capotorti, G.; Blasi, C.; Salvatori, E.; Fusaro, L.; Ciancarella, L.; Mircea, M.; Marchetti, M.; Chirici, G.; et al. Regulating ecosystem services of forests in ten Italian metropolitan cities: Air quality improvement by PM10 and O3 removal. Ecol. Indic. 2016, 67, 425-440. [CrossRef]

140. Vymazal, J. Removal of nutrients in various types of constructed wetlands. Sci. Total Environ. 2007, 380, 48-65. [CrossRef]

141. Howes, D.J.; Fox, P.; Hutton, P.H. Evapotranspiration from Natural Vegetation in the Central Valley of California: Monthly Grass Reference-Based Vegetation Coefficients and the Dual Crop Coefficient Approach. J. Hydrol. Eng. 2015, 20(10), 04015004. [CrossRef]

142. Shashua-Bar, L.; Pearlmutter, D.; Erell, E. The cooling efficiency of urban landscape strategies in a hot dry climate. Landsc. Urban Plan. 2009, 92, 179-186. [CrossRef]

143. Ye, G.; Yang, C.; Chen, Y.; Li, Y. A new approach for measuring predicted mean vote (PMV) and standard effective temperature (SET $*$ ). Build. Environ. 2003, 38, 33-44. [CrossRef] 
144. Fischer, E.; Schär, C. Consistent geographical patterns of changes in high-impact European heatwaves. Nature Geosci. 2010, 3 , 398-403. [CrossRef]

145. Baró, F.; Haase, D.; Gómez-Baggethun, E.; Frantzeskaki, N. Mismatches between ecosystem services supply and demand in urban areas: A quantitative assessment in five European cities. Ecol. Indic. 2015, 55, 146-158. [CrossRef]

146. Rossman, L.A. Storm Water Management Model User's Manual Version 5.1; US EPA: Cincinnati, OH, USA, 2015.

147. Lennox, M.S.; Lewis, D.J.; Jackson, R.D.; Harper, J.; Larson, S.; Tate, K.W. Development of vegetation and aquatic habitat in restored riparian sites of California's north coast rangelands. Restor. Ecol. 2011, 19, 225-233. [CrossRef]

148. Baró, F.; Chaparro, L.; Gómez-Baggethun, E.; Langemeyer, J.; Nowak, D.J.; Terradas, J. Contribution of ecosystem services to air quality and climate change mitigation policies: The case of urban forests in Barcelona, Spain. Ambio 2014, 43, 466-479. [CrossRef] [PubMed]

149. Xiao, Q.; McPherson, E.G. Rainfall interception by Santa Monica's municipal urban forest. Urban Ecosyst. 2002, 6, 291-302. [CrossRef]

150. Soares, A.L.; Rego, F.C.; McPherson, E.G.; Simpson, J.R.; Peper, P.J.; Xiao, Q. Benefits and costs of street trees in Lisbon, Portugal. Urban For. Urban Green. 2011, 10, 69-78. [CrossRef]

151. Deng, Y.; Cardin, M.-A.; Babovic, V.; Santhanakrishnan, D.; Schmitter, P.; Meshgi, A. Valuing flexibilities in the design of urban water management systems. Water Res. 2013, 47, 7162-7174. [CrossRef]

152. Aboelata, A. Assessment of green roof benefits on buildings' energy-saving by cooling outdoor spaces in different urban densities in arid cities. Energy 2021, 219, 119514. [CrossRef]

153. WWF; ILO. Nature Hires: How Nature-Based Solutions Can Power a Green Jobs Recovery; WWF: Gland, Switzerland; ILO: Geneva, Switzerland, 2020.

154. Barton, D.N.; Vågnes Traaholt, N.; Blumentrath, S. Materials and methods appendix for valuation of ecosystem services of green infrastructure in Oslo. NINA Rapport; NINA: Oslo, Norway, 2015; ISBN 978-82-426-2737-7. ISSN 1504-3312.

155. Stessens, P.; Khan, A.Z.; Huysmans, M.; Canters, F. Analysing urban green space accessibility and quality: A GIS-based model as spatial decision support for urban ecosystem services in Brussels. Ecosyst. Serv. 2021, 28((Part C)), 328-340. [CrossRef]

156. Mears, M.; Brindley, P. Measuring Urban Greenspace Distribution Equity: The Importance of Appropriate Methodological Approaches. ISPRS Int. J. Geo-Inf. 2019, 8, 286. [CrossRef]

157. Cohen, M.; Baudoin, R.; Palibrk, M.; Persyn, N.; Rhein, C. Urban biodiversity and social inequalities in built-up cities: New evidences, next questions. The example of Paris, France. Landsc. Urban Plan. 2012, 106, 277-287. [CrossRef]

158. Felson, M.; Poulsen, E. Simple indicators of crime by time of day. Int. J. Forecast. 2003, 19, 595-601. [CrossRef]

159. Reed, M.S.; Graves, A.; Dandy, N.; Posthumus, H.; Hubacek, K.; Morris, J.; Prell, C.; Quinn, C.H.; Stringer, L.C. Who's in and why? A typology of stakeholder analysis methods for natural resource management. J. Environ Manage. 2009, 90, $1933-1949$. [CrossRef] [PubMed]

160. Stafford, M.; Bartley, M.; Sacker, A.; Marmot, M.; Wilkinson, R.; Boreham, R.; Thomas, R. Measuring the social environment: Social cohesion and material deprivation in English and Scottish neighbourhoods. Environ. Plan. A. 2003, 35, 1459-1475. [CrossRef]

161. Roe, J.J.; Ward Thompson, C.; Aspinall, P.A.; Brewer, M.J.; Duff, E.I.; Miller, D.; Mitchell, R.; Clow, A. Green space and stress: Evidence from cortisol measures in deprived urban communities. Int. J. Environ. Res. Public Health. 2013, 10, $4086-4103$. [CrossRef] [PubMed]

162. White, M.P.; Alcock, I.; Grellier, J. Spending at least 120 minutes a week in nature is associated with good health and wellbeing. Sci. Rep. 2019, 9, 7730. [CrossRef] [PubMed]

163. Kim, J.H.; Lee, C.; Olvara, N.E.; Ellis, C.D. The role of landscape spatial patterns on obesity in hispanic children residing in inner-city neighborhoods. J. Phys. Act. Health 2014, 11, 1449-1457. [CrossRef] [PubMed]

164. Villeneuve, P.J.; Jerrett, M.; Su, J.G.; Burnett, R.T.; Chen, H.; Wheeler, A.J.; Goldberg, M.S. A cohort study relating urban green space with mortality in Ontario, Canada. Environ. Res. 2012, 115, 51-58. [CrossRef] [PubMed]

165. Donovan, G.H.; Butry, D.T.; Michael, Y.L.; Prestemon, J.P.; Liebhold, A.M.; Gatziolis, D.; Mao, M.Y. The relationship between trees and human health. Am. J. Prev. Med. 2013, 44, 139-145. [CrossRef] 